\title{
ÜLDISE MUUTUMISTÄHENDUSEGA VERBID JA NEID SISALDAVAD LAUSETÜÜBID LÄÄNEMERESOOME KEELTES $^{1}$
}

\author{
MIINA NORVIK
}

Annotatsioon. Artiklis analüüsitakse üldise muutumistähendusega verbe läänemeresoome keeltes. Keeltest/keelevariantidest on tähelepanu keskmes lutsi, vadja, isuri, lüüdi, vepsa ja Valdai karjala. Kuna eesti, soome ja liivi keeles leiduvaid muutusverbe on juba varemgi uuritud, siis nende keelte kohta saadud uurimistulemusi kasutatakse võrdlusmaterjalina. Lähema vaatluse all on verbid JÄÄDA, LEEDA, MINNA, SAADA, SÜNDIDA, TEHA ja TULLA, millega väljendatakse vähemalt mingis läänemeresoome keeles muutust. Artiklis uuritakse nende tarvitust intransitiivsetes konstruktsioonides. Eesmärk on välja selgitada, kuidas nimetatud verbide tarvitus keeliti erineb/sarnaneb ja lausetüübiti varieerub ning mida see keeltes leiduva erisuguse kasutussageduse kohta näitab. Analüüsitud keelematerjal pärineb läänemeresoome keelte tekstikogumikest, välitööde käigus tehtud lindistustelt ja mõningal määral ka sõnaraamatutest.

Võtmesõnad: morfosüntaks, intransitiivsed konstruktsioonid, poolkoopula, läänemeresoome keeled

\section{Sissejuhatus}

Muutuse väljendamine on enamasti seotud mingi uue seisundi algusega, mida võiks käsitleda kui muutust $\mathrm{A} \rightarrow \mathrm{B}$, kusjuures üldiselt on rõhuasetus uuel seisundil (Radden, Dirven 2007: 274; Clancy 2010: 9). Nii võib näite (1a) põhjal järeldada, et taustal on varasem seisund, mida võiks väljendada lausega (1b). Muutust võib siiski käsitleda ka laiemalt. Nii on muutus seostatav ka millegi tekkimise, eksisteerima hakkamise (2), omatava siirdumisega ühelt omajalt teisele (nt Radden, Dirven 2007: 281). Samuti

${ }^{1}$ Artikli valmimist on toetanud Eesti Teadusagentuur (PUTJD926). 
võib muutust, kuigi fiktiivset, näha isegi olukorra edasikestmises (vt nt soome jäädä 'jääda' kasutuse kohta Huumo 2007) või tajuda seda vähemalt tagaplaanil olevana isegi tulevikulises lauses (vt täpsemini altpoolt).

(1a) Laps jäi haigeks

(1b) Laps oli terve

(2) Tuli kevad

Siinses artiklis ongi muutust käsitletud laiemas tähenduses. Samas on teema piiritlemise eesmärgil vaatluse all vaid intransitiivsetes konstruktsioonides leiduvad verbid, millega väljendatakse vähemalt ühes läänemeresoome keeles muutust: JÄÄDA², LEEDA, MINNA, SAADA, SÜNDIDA, TEHA ja TULLA. Kui mingis keeles on üks nimetatud verbidest osutunud laialt levinuks enamikus muutusega seostatavates konstruktsioonides, on seda järgnevalt nimetatud ka üldiseks muutusverbiks. (Läänemeresoome keeleala kõige tüüpilisemate verbide väljaselgitamise kohta vt Norvik (2020), millel siinne artikkel osalt põhineb.)

Artiklis analüüsitavad verbid seostuvad ennekõike nominaalse või adverbiaalse lauseelemendiga, moodustades selliselt semantilise predikaadi, kusjuures verb kannab verbikategooriaid, kuid lisab ka mõningast semantilist sisu (vt 1a, 2, 3). Eesti keele süntaksikirjelduses on selliseid verbe nimetatud poolkopulatiivseteks, eristades neid kopulatiivsest olla-verbist (nt 1b) (vt Erelt 2017a: 279). Termin poolkopulatiivne (ing1 semi-copula, vahel ka quasi-copula) viitabki sellele, et verbil on enam semantilist sisu kui täieõiguslikul koopulal, samas on koopula ja poolkoopula sarnased selle poolest, et kumbki ei moodusta üksi predikaati (Pustet 2003: 5-6). Terminit koopula võib siiski kohata ka katusterminina, kui täpsem eristus pole vajalik.

(3) Mees läks marru

Artikli eesmärk on uurida ülal nimetatud verbide käitumist intransitiivsetes konstruktsioonides ning tuua lausetüüpide kaupa välja keeltevahelised sarnasused ja erinevused muutuse väljendamisel. Selliselt soovitakse välja

2 Kuna läänemeresoome keeltes on tavapärane kasutada algvormina $d a$-infinitiivivormi, on ühtluse huvides ka eesti keele verbide puhul eelistatud $d a$-infinitiivi. Järgnevalt kasutatakse läbivat suurtähte, kui tahetakse tuua ühe katusmõiste alla kokku sama tüve ja tähendusega seotud vormid eri läänemeresoome keeltes, nt koondab TULLA enda alla eesti tulla, liivi tūlda, vadja tulla, vepsa tulda jne (vt suurtähtede kasutamise kohta Dahl 2000b). 
selgitada, mis tähendusi võivad need verbid eri lausetüüpides kanda ning mis seoseid võib eri lausetüüpide vahel täheldada. Kuna kõigis keeltes on muutus seostatav enam kui ühe vaatlusaluse verbiga, kuigi erineval määral, võiks siinne vaatenurk anda muu hulgas selgust, mis erineva kasutussageduse tingib ning milliseid arenguteid/seoseid tüüpide vahel ilmneb. Eraldi tähelepanu all on arengutee poolkopulatiivne $\rightarrow$ kopulatiivne verb (siinkohal on koopula all mõeldud siiski üksnes tulevikukoopulat). Arenguahela MUUTUS $\rightarrow$ TULEVIK on võimalike grammatisatsiooniteede seas esitanud ka Bernd Heine ja Tania Kuteva (2002), kes ilmestavad seda saksa keele näitega (4a). Kuna tulevikuline olukord eeldab üldiselt nii selle kehtima hakkamist kui ka jätkumist, ei puudu muutuse tähendus tulevikulisest lausest siiski täielikult, tihtipeale on pigemini tegu muutuse ja olema saamise tähenduse põimumise kui puhta tulevikuga (nt Dahl 2000a). Seda kinnitavad ka lause (4a) eestikeelsed tõlked. Seevastu minevikulises lauses tuleb selgelt esile verbi werden muutuse tähendus (vrd 4b) (vt ka Heine 1993: 62), mis lähtub tüvest *wert- 'keerama' (Kluge 1995). Vaheastme MUUTUS olulisust tulevikuvahendite kujunemisel soome-ugri keeltes on näidanud ka Helle Metslang (1994, 1996).

(4a) Er wird Arzt

tema saa.3sg arst

'Temast saab arst / Tema saab olema arst' (Heine, Kuteva 2002: 318)

(4b) $\mathrm{Er} \quad$ wurde Artzt

tema saa.PST.3sG arst

'Temast sai arst'

Uuritav materjal pärineb kuuest läänemeresoome keele(variandi)st, milleks on isuri, lutsi (Eesti kunagine keelesaar Lätis), lüüdi, vadja, Valdai karjala ja vepsa. Iga keel on valimis esindatud 100 näitega. Eesti, soome ja liivi keel on aga esindatud varasemate uurimistulemuste põhjal, kuna neis leiduvaid muutuskonstruktsioone on varemgi käsitletud nii tähendusest kui ka konstruktsioonist lähtudes (eesti keele kohta vt nt Pajusalu, Tragel 2007, soome keele kohta Tommola 2010, liivi keele kohta Norvik 2014a). Ühtlasi lähtutakse siinses artiklis uurimusest, mille eesmärk oli selgitada välja eri läänemeresoome keeltele iseloomulikud muutusverbid (Norvik 2020).

Artikkel on üles ehitatud järgmiselt: osas 2 antakse ülevaade sellest, mis lausetüüpidega võib eesti, soome ja liivi keeles muutuse väljendamist 
seostada ning mis väljendusvahendeid leidub; osas 3 tutvustatakse materjali ja analüüsimeetodit; osas 4 esitatakse uurimistulemused lausetüüpide kaupa, võrreldes keeli omavahel; osas 5 tuuakse esile seosed lausetüüpide vahel ja nendega seostuvad võimalikud arenguteed; osas 6 esitatakse kokkuvõte.

\section{2. (Pool)kopulatiivsed verbid eesti, soome ja liivi keeles}

Eesti, soome ja liivi keeles käitub kopulatiivse verbina OLLA-verb, millele semantilise sisu lisab öeldistäide (vt 5a). Nii jääb näide (5b) ilma kontekstita pigem poolikuks: see võiks küll väljendada eksisteerimist, kuid sellisel juhul oleks ootuspärane, et sõnale on järgneks verbivorm olemas. Liivi keeles eristub ka tulevikukoopula līdõ 'leeda', sest sugugi mitte harvad pole juhud, kus sellega väljendatakse olemist tulevikus (6). Erinevalt OLLA-verbist ei saa LEEDA-verbi siiski käsitada pelga köitmena, sest tulevikuga võib seostada teatavat muutust, kohati ka modaalset varjundit ning mõnes läänemeresoome keeles märgitakse LEEDA-verbiga koguni muutust minevikulises lauses (7) (vt Norvik 2015; vrd ka saksa werden kasutust osas 1). Seetõttu ongi siinses töös võetud vaatluse alla LEEDA, samas kui OLLA on välja jäetud.

(5a) Ta on tantsija

(5b) ?Ta on

(6) ne umārd lībəd nei' knaššəd need oun.PL lee.3PL nii ilus.PL

'Need õunad saavad olema nii ilusad' (liivi, Setälä 1953: 105)

(7) mie lieńīn kohtune mina lee.PST.1SG rase

'Ma jäin rasedaks' (Valdai karjala, Palmeos 1962: 84)

Eesti keele süntaksikirjelduses on poolkopulatiivsete verbidena mainitud üldise seisundimuutuse tähendusega verbe tulla, saada ja jääda (Erelt 2017a: 279-281). Renate Pajusalu ja Ilona Tragel (2007) on nende verbide kõrval analüüsinud muutuse väljendamise seisukohalt ka minna-verbi, pöörates sealjuures tähelepanu eri tüüpi konstruktsioonidele. Eristus põhineb sellel, kas muutusele alluv osaline on nominatiivis (NOM-changeconstruction) või elatiivis (ELA-change construction), vt vastavalt näiteid

${ }^{3}$ Siin ja edaspidi on keelenäited esitatud nii, nagu algallikas. 
(8) ja (9). Mati Erelt (2005) lähtub oma liigituses aga sellest, kas markeeritud on siht (goal-marking) või lähe (source-marking). Need käsitlusviisid siiski ei vastandu teineteisele. Nimelt kui muutusele alluv osaline on markeerimata, siis tulemusseisund on üldiselt markeeritud, olles enamasti väljendatud translatiivi, allatiivi või seisundimäärusega (vt lõhki näites 8). Näiteid tulemusseisundi markeerimata jäämise kohta leidub eesti keelest üksikuid (10), seevastu karjala keeles on selline olukord tavaline ( $\operatorname{vrd} 7)$. Lähte markeerimine aga tähendabki elatiivset markeerimist, mille korral on tulemusseisund markeerimata (vt tublid mehed näites 9).

(8) Püksid läksid lõhki

(9) Poistest tulid/said tublid mehed (Erelt 2017a: 279)

(10) Sõlm sai tugev (Erelt 2017b: 290)

Lausetüübi järgi on näited (8) ja (10) normaallaused, näide (9) aga tulemuslause. Normaallausete hulka tavatsetakse lisaks lugeda sellised juhud, kus alus on välja jäetud ning öeldistäitega iseloomustatakse olukorda mingis ajas või kohas (11). Veel on poolkopulatiivsena käsitletud kogejalausetes esinevat hakata-verbi, mida laiendab öeldistäide (Erelt 2017a: 280-281), vt näidet (12). Nendel juhtudel paikneb lause teema osas tegevussubjekt (muutuse kogeja), kes/mis teeb mingil viisil läbi muutuse seisund $1 \rightarrow$ seisund 2 .

(11) Väljas läks külmaks

(12) Tal hakkas paha

Intransitiivsetest konstruktsioonidest võib muutusega mõnevõrra kaudsemini seostada olemasolu- ja omajalauset. Nendel puhkudel ei ole osalist, mis muutuks, vaid pigem väljendatakse mingi olukorra kehtima hakkamist (13), omandisuhete muutust, sh millegi enda valdusesse saamist või millestki ilmajäämist (14). Kõnealuseid lausetüüpe on muutuse seisukohalt käsitletud liivi keele muutusverbide uurimisel (vt Norvik 2014a), aga ka näiteks soome JÄÄDA-verbi analüüsimisel (vt Huumo 2007). Soome keele grammatikas käsitletakse muutuse väljendamist ühelt poolt konstruktsioonist lähtudes, eristades seisundimuutusmalli (tilanmuutosmuotti) ning selle alaliikidena intransitiivset muutumis- ja eesmärgimalli (muuttumis-ja tarkoitusmuotti), mida saab seostada kindlate verbidega, nt muuttua 'muutuda', jäädä 'jääda', mennä 'minna' (VISK § 481). Teisalt on muutuse väljendamist puudutatud lausetüüpide all (vt VISK § 891-904), kuigi tüüpide eristusel toodud näited sisaldavad enamjaolt kopulatiivset 
OLLA-verbi. Samuti on eesti keele käsitlustes poolkopulatiivsete verbide kasutus eeskätt olemasolu-, kogeja- ja omajalauses vähe tähelepanu leidnud. Siinses artiklis lähtutakse just lausetüübist, et poolkopulatiivsetest verbidest neis tüüpides võimalikult laia pilti anda ning neid staatilise sisuga OLLA-verbi sisaldavate lausete kõrval paremini esile tuua.

(13) Tuli sõda

(14) Mulle jäi vaid üks kassipoeg

Lähtudes eesti keele lausetüüpide liigitusest, on ülal toodud näited esitatud tabelis 1 . Sealjuures on lisatud näiteid verbide kohta, mis võivad vaadeldavas konstruktsioonis esineda, ilma et nominaalset/adverbiaalset lauseelementi peaks muutma. Erandi moodustab lause Ta oli tantsija, millest pole võimalik teha muutust märkivat lauset öeldistäite käänet muutmata (*Ta läks/sai/tuli/jäi/... tantsija $\rightarrow$ Temast sai tantsija / Ta sai tantsijaks vms), kuid kuna selle tüübi kohta leidub näiteid teistest läänemeresoome keeltest, on see rida siiski tabelis (tähistatud kriipsudega). Kuna muutuse väljendamine on ühemõttelisem minevikulises kui tulevikulises lauses, on näited esitatud minevikuvormis.

Tabel 1. Muutuse väljendamine eesti keeles lausetüüpide kaupa

\begin{tabular}{|c|c|c|c|c|c|c|c|c|}
\hline \multirow[b]{2}{*}{$\begin{array}{c}\text { LAUSE } \\
\text { PÕHI- } \\
\text { Tய̈ÜP }\end{array}$} & \multicolumn{2}{|c|}{ TEEMA } & \multicolumn{6}{|c|}{ REEMA } \\
\hline & Alus & Määrus & $\begin{array}{c}\text { Pool- } \\
\text { koopula }\end{array}$ & Fraas & Alus & $\begin{array}{c}\text { Öeldis- } \\
\text { täide }\end{array}$ & $\begin{array}{l}\text { Öeldis- } \\
\text { täite- } \\
\text { määrus }\end{array}$ & $\begin{array}{c}\text { Sei- } \\
\text { sundi- } \\
\text { määrus }\end{array}$ \\
\hline \multirow{6}{*}{$\begin{array}{l}\text { Normaal- } \\
\text { lause }\end{array}$} & - & & - & $\mathrm{NP}_{\mathrm{Nom}}$ & & - & & \\
\hline & $T a$ & & sai & $\mathrm{NP}_{\text {Tra }}$ & & & tantsijaks & \\
\hline & Sõlm & & $\begin{array}{l}\text { sai/tuli/ } \\
\text { jäi }\end{array}$ & $\operatorname{Adj} P_{\text {Nom }}$ & & tugev & & \\
\hline & Laps & & \begin{tabular}{|l|l}
$j a ̈ i$ \\
\end{tabular} & $\operatorname{Adj}_{\text {Tra }}$ & & & haigeks & \\
\hline & & Väljas & läks & $\operatorname{Adj}_{\text {Tra }}$ & & & külmaks & \\
\hline & Püksid & & läksid & AdvP & & & & lõhki \\
\hline $\begin{array}{l}\text { Tulemus- } \\
\text { lause }\end{array}$ & & Poistest & $\begin{array}{l}\text { tulid/ } \\
\text { said }\end{array}$ & $\mathrm{NP}_{\mathrm{Nom}}$ & $\begin{array}{l}\text { tublid } \\
\text { mehed }\end{array}$ & & & \\
\hline $\begin{array}{l}\text { Kogeja- } \\
\text { lause }\end{array}$ & & Tal & hakkas & $\operatorname{Adj} P_{\text {Nom }}$ & & paha & & \\
\hline $\begin{array}{l}\text { Olemasolu- } \\
\text { lause }\end{array}$ & & & \begin{tabular}{|l|} 
Tuli/ \\
hakkas
\end{tabular} & $\mathrm{NP}_{\mathrm{Nom}}$ & sõda & & & \\
\hline $\begin{array}{l}\text { Omaja- } \\
\text { lause }\end{array}$ & & Mulle & jäi/sai & $\mathrm{NP}_{\mathrm{Nom}}$ & $\begin{array}{l}\text { kassi- } \\
\text { poeg }\end{array}$ & & & \\
\hline
\end{tabular}


Tabelist 1 nähtub, et kuigi nii jääda, hakata, minna, saada kui ka tulla on seostatavad muutusega, ei leidu ühtegi näidet, kus kõik viis verbi oleksid võimalikud. Siiski pole tabeli 1 puhul tegu lõpliku tabeliga selle kohta, mis konstruktsioonides mingi verb võiks esineda. Näiteks konstruktsioonis $\mathrm{NP}_{\text {Nom }} \mathrm{V}_{\text {poolkoopula }} \mathrm{Adj}_{\text {Tra }}$ on peale verbi jääda (Laps jäi haigeks) võimalik ka saada, kui öeldistäitemäärus välja vahetada (vrd Laps sai terveks). Selliste näidete tõttu ongi oluline pöörata tähelepanu ka leksikaalsetele erisustele.

Pajusalu ja Tragel (2007: 306) on näidanud, et eesti verbide minna, tulla, jääda ja saada valikut võib käsitleda positiivsuse-negatiivsuse skaalal, mis seostuvad kolme põhilise domeeniga: 1) kvantiteet (tõus vs. langus), 2) eesmärgipärasus, tegevus (aktiivsus vs. passiivsus), 3) muutusele alluva osalise hinnang seisundile (paranemine vs. halvenemine). Näide (15) ilmestab tõusu vs. langust, näide (16) aga seisundi paranemist vs. halvenemist. Seega on konstruktsiooni valikul vähemalt osaliselt leksikaalsed põhjused (Pajusalu, Tragel 2007: 300). Näiteks on soome keeles positiivsuse-negatiivsuse skaalal käsitletud verbe mennä 'minna' ja tulla 'tulla', seostades neist esimest pigem negatiivse muutusega, teist aga positiivse muutusega (17) (Onikki-Rantajääskö 2001; Huumo, Sivonen 2010; sarnase vastanduse kohta inglise keeles vt Radden, Dirven 2007: 274-275). Sealhulgas on näidatud, et pelga positiivsuse vs. negatiivsuse kõrval on oluline arvesse võtta muidki nüansse, nagu agentiivsus, teadlikkus (Huumo, Sivonen 2010). Üldiselt on nii eesti kui ka soome keele puhul tõdetud, et süsteem ei tööta eranditeta, kuid põhijoontes ikkagi toimib. Huvitavat võrdlusainest pakub aga liivi keel, kus erinevalt eesti keelest ei näi JÄÄDA- ja SAADA-verbi korral positiivsuse-negatiivsuse skaala toimivat. Pigem tõuseb iedõ 'jääda' esile vägagi üldise muutusverbina (vrd eestikeelsetes tõlgetes kasutatud verbide hulka): iedõ rujāks 'jääda haigeks', iedõ tierrõks 'saada terveks', iedõ kivīks/ki'vkõks 'muutuda kiviks', iedõ punīzõks 'minna punaseks'. Sellises JÄÄDA-verbi üldistumises võib näha läti mõju (vt Norvik 2014a), kus eriti just suulises keeles võib täheldada verbi palikt 'jääda' kasutuse laienemist verbi kļüt 'saada' arvelt (Ivulāne 2015: 40).

(15) Vihm läks tugevamaks

(16) Mees sai terveks

(17) Kone meni

masin mine.PST.3sG katki

'Masin läks katki vs. sai korda' vs. jäi nõrgemaks

$v s$. jäi haigeks

vs. tuli kuntoon

tule.PST.3SG kord.ILL 
Juba mõne näite varal ilmnevad lähedaste sugulaskeelte vahelised erinevused (vrd soomekeelset näidet (17) ja selle eestikeelset tõlget). Samuti ei õnnestuks näiteid (15) ja (16) tõlkida soome keelde eesti keele malli järgides (vt ka Tommola 2010). Kui aga eesti ja soome keelt on muutuse väljendamise seisukohalt omavahel võrreldud (nt Pajusalu 1994; Tommola 2010) ning omaette tähelepanu on saanud ka eesti keelele lähedane sugulaskeel liivi keel (Norvik 2014a), siis kõrvutavaid uurimusi, mis võtaks arvesse ka teisi läänemeresoome keeli, on vähe (vt siiski Norvik 2020). Seda tühimikku üritabki siinne artikkel täita.

\section{Materjal ja meetod}

Artiklis analüüsitav materjal (kokku 600 näidet) pärineb peamiselt tekstikogumikest, välitöödel kogutud materjalist, osaliselt ka tekstikorpustest. Kui sõnaraamatustest kogutud lauseid on artiklis kasutatud pigem võrdlusmaterjalina (st mitte põhivalimi hulgas, vt täpsemini altpoolt), siis isuri keele puhul tuli põhivalimi hulka võtta ka sõnaraamatust kogutud näited, sest tekstikogumikest ei õnnestunud vajalikku arvu (100 näidet keele kohta) kokku saada. Näitematerjali allikad on koondatud tabelisse 2. Keelte juures on nimetatud ka murded, mille kohta leidus lõplikus andmestikus näiteid.

Tabel 2. Analüüsitava materjali allikad

\begin{tabular}{|l|l|l|l|l|}
\hline \multicolumn{1}{|c|}{ Keel } & \multicolumn{1}{|c|}{$\begin{array}{c}\text { Tekstikogu- } \\
\text { mikud }\end{array}$} & $\begin{array}{c}\text { Keelematerjali } \\
\text { kogumise aeg }\end{array}$ & $\begin{array}{l}\text { Välitöö- } \\
\text { materjal }\end{array}$ & $\begin{array}{c}\text { Sõna- } \\
\text { raamatud }\end{array}$ \\
\hline lutsi & EM IX & $\begin{array}{l}\text { 1910.-1930. ja } \\
1950 .-1970 . \text { aastad }\end{array}$ & & \\
\hline $\begin{array}{l}\text { isuri (Hevaha, } \\
\text { Soikkola, Alam- } \\
\text { Luuga, Oredeži) }\end{array}$ & $\begin{array}{l}\text { Laanest 1966; } \\
\text { Porkka 1885 }\end{array}$ & $\begin{array}{l}\text { 1959-1963; } \\
1884\end{array}$ & $\begin{array}{l}\text { Laanest } \\
1997 \\
\text { Nirvi 1971 }\end{array}$ \\
\hline $\begin{array}{l}\text { vadja (lääne- } \\
\text { ja idavadja) }\end{array}$ & $\begin{array}{l}\text { Adler 1968; } \\
\text { Ariste 1962, } \\
1977,1982\end{array}$ & $\begin{array}{l}\text { 1960ndad; } \\
1940 .-1970 . \text { aastad }\end{array}$ & VKS \\
\hline $\begin{array}{l}\text { vepsa } \\
\text { (põhja-, kesk- } \\
\text { ja lõunavepsa) }\end{array}$ & $\begin{array}{l}\text { Kettunen } \\
\text { NV20; } \\
\text { NVM 1935; }\end{array}$ & $\begin{array}{l}1917-1918 ; 1934 ; \\
\text { OVR 1969-1966 }\end{array}$ & $\begin{array}{l}\text { Norvik } \\
2014 b\end{array}$ & $\begin{array}{l}\text { Zaiceva, } \\
\text { Mullonen } \\
2007\end{array}$ \\
\hline $\begin{array}{l}\text { lüüdi (põhja- } \\
\text { ja kesklüüdi) }\end{array}$ & LK 1934 & 1909 ja 1920ndad & $\begin{array}{l}\text { Norvik } \\
2012\end{array}$ & $\begin{array}{l}\text { Kujola } \\
1944\end{array}$ \\
\hline Valdai karjala & Palmeos 1962 & 1950ndad & & \\
\hline
\end{tabular}


Analüüsi aluseks olnud keelematerjal on võrdlemisi heterogeenne nii allikate mõttes kui ka kogumisaega arvestades. Sellega on tulemuste esitlemisel ka arvestatud. Siiski on kogutud materjal sarnane selle poolest, et põhiosa näidetest pärineb peaaegu kõigi keelte puhul 1950.-1960. aastatest. Suuresti on need ka sama tüüpi tekstid: muinasjutud, muistendid ja meenutused endisajast. Enamik vepsa ja lüüdi näiteid on küll 20. sajandi esimesest poolest, kuid samas on olnud kasutada peaaegu sada aastat hiljem kogutud materjal. See on andnud võimaluse teha järeldusi ka võimalike muutuste kohta. Valdai karjalast ja lutsist poleks uuemat materjali olnud ka võimalik arvesse võtta, sest need keelesaared hääbusid juba 20. sajandi teisel poolel. Nagu artiklist selgub, joonistuvad kogutud andmete põhjal teatavad kasutustendentsid selgelt välja, mistõttu töö õigustab ennast.

Kasutatud allikatest koguti esmalt sellised näitelaused, mis sisaldasid muutust märkivat verbi intransitiivses konstruktsioonis (vt tabelis 1 esitatud lause põhitüüpe). Kui kuskilt keelest oli juba muutust märkiv verb üles kirjutatud, püüti seda teha ka teistest keeltest materjali kogudes. Selliselt sattusid lõplikku valimisse verbid JÄÄDA, LEEDA, MINNA, SAADA, SÜNDIDA, TEHA ja TULLA ning nende vasted teistes läänemeresoome keeltes (vt koondtabelit 10).

Kõigepealt määrati uuritavat verbi sisaldava lause põhitüüp: normaal-, tulemus-, kogeja-, olemasolu- ja omajalause. Normaallause all eristati sealjuures järgmisi tüüpe: 1) nominatiiviga väljendatud tulemusseisund, 2) translatiivi või essiiviga väljendatud tulemusseisund, 3) kohakäände või adverbiga väljendatud tulemusseisund (vrd tabelit 1). Seejärel märgendati nominaalsed ja adverbiaalsed lauseelemendid, pöörates tähelepanu ka tähendusele. Verbi puhul määrati aja- ja pöördevorm.

Lõplikus valimis on iga keel esindatud 100 näitega. Need valiti välja juhuslike arvude generaatoriga. Sellel valimil põhineb lause põhitüüpidest lähtuv tulemuste tutvustus osas 4. Igat alaosa alustab tabel, kust selgub, mitu korda 100 näite hulgas struktuuritüüpi esines. Kolm kokkuvõtvat tabelit on lisas.

Leksikaalsete erinevuste kohta järelduste tegemisel on võimaluse korral arvesse võetud ka neid näiteid, mis jäid 100 näidet sisaldava valimi hulgast välja, sest paari näite alusel on kohati keeruline terviklikku ja tõest pilti anda. Kirjaliku allikmaterjali vähesuse tõttu ei ole lisanäiteid siiski õnnestunud koguda isuri ja Valdai karjala keelevariantidest. Kui järeldus põhineb lisanäidetel, on seda eraldi mainitud. 
Kõik keelenäited peale eesti näidete on glossitud ja varustatud tõlkega. Keelenäidete esitamisel on lähtutud algallikast ning toodud võimalikult täpne murdeinfo.

\section{Muutuse ja sellega seotud tähenduste väljendamine lause põhitüüpide kaupa}

Järgnevalt esitatakse analüüsi tulemused, vaadeldes verbide JÄÄDA, LEEDA, MINNA, SAADA, SÜNDIDA, TEHA ja TULLA käitumist muutuse väljendamisel viies lause põhitüübis: normaal-, tulemus-, kogeja-, olemasolu- ja omajalauses (vt koondtabeleid lisas). Varasematele uurimustele tuginedes tuuakse paralleele eesti, soome ja liivi keelega.

\subsection{Normaallause}

\subsubsection{Translatiivne ja essiivne tulemusseisund}

Tabel 3. Muutusverbide esinemus normaallauses struktuuriga $\mathrm{NP}_{\mathrm{Nom}} \mathrm{V}$ Adj $\mathrm{P}_{\text {Tra }} / \mathrm{NP}_{\text {Tra/Ess }}$

\begin{tabular}{|l|c|c|c|c|c|c|c|}
\hline Verb/Keel & isuri & lutsi & lüüdi & V. karj & vadja & vepsa & Kokku \\
\hline JÄÄDA & 11 & 11 & & 1 & 4 & 3 & $\mathbf{3 0}$ \\
\hline SAADA & 8 & 5 & & & 2 & & $\mathbf{1 5}$ \\
\hline LEEDA & & & 1 & 1 & 3 & 1 & $\mathbf{6}$ \\
\hline SÜNDIDA & & & 2 & & & & $\mathbf{2}$ \\
\hline TULLA & 14 & & 1 & & 9 & & $\mathbf{2 4}$ \\
\hline MINNA & 3 & & & & 7 & 2 & $\mathbf{1 2}$ \\
\hline TEHA & & 1 & & & & 3 & $\mathbf{4}$ \\
\hline Kokku & $\mathbf{3 6}$ & $\mathbf{1 7}$ & $\mathbf{4}$ & $\mathbf{2}$ & $\mathbf{2 5}$ & $\mathbf{9}$ & $\mathbf{9 3}$ \\
\hline
\end{tabular}

Siinse tüübi alla on paigutatud juhud, kus öeldistäitemäärus on ennekõike translatiivikäändeline NP või AdjP, mis väljendab tulemusseisundit (18 ja 19). Lisaks on siia alla arvatud ka essiiviga näited, mida valimisse sattus vaid paar: Valdai karjalast 1, vepsa keelest 1 (nt 20) ja vadja keelest 2. Seetõttu pole neid ka tabelis eraldi esitatud. Samuti võiksid sellesse tüüpi kuuluda aluseta laused, kus öeldistäitemäärus ilmestab olukorda ajas või kohas, nagu eesti näites (21). Vaadeldavasse tüüpi liigitatud näidete hulgas 
polnud aga ühtegi aluseta translatiivi sisaldavat näidet (küll aga esines näiteid nominatiiviga, vt osa 4.1.2).

(18) eleetta nuoręd. tulettta vanassi

ole.2PL noor.PL tule.2PL vana.TRA

'Olete noored. Jääte vanaks' (läänevadja, Ariste 1982: 12)

(19) hää rod'īhe hüviń t'ühjäkši

ta sündi.PST.REFL.3sG väga vaene.TRA

'Ta jäi väga vaeseks' (kesklüüdi, Kujola 1944: 362)

(20) sinä l'ińńed vanhamban mīl'

sina lee.2SG vanem.ESs meie.ADE

'Sina saad meil olema vanemaks' (keskvepsa, NVM 1935: 63)

$(21=11)$ Väljas läks külmaks

Enamikul juhtudest väljendatakse kõnealuse konstruktsiooniga muutust, st seisund $1 \rightarrow$ seisund 2 (nt rikas $\rightarrow$ vaene, noor $\rightarrow$ vana, soe $\rightarrow$ külm). Vaid JÄÄDA puhul leidus muutust väljendavate näidete kõrval ka selliseid, mis märgivad varasema seisundi edasikestmist. Nimelt kui näite (22) korral on tegu muutusega nägija $\rightarrow$ pime, siis lauses (23) soovitakse seisundi (terve olemine) edasikestmist. Samas võib ka seisundi edasikestmist (vt 23) käsitada kui muutust, kuigi fiktiivset, mille korral jääb mingi alternatiivne olukord realiseerumata; muutusele omaselt on tulemusseisund väljendatud translatiivi abil (vt JÄÄDA-verbiga väljendatava fiktiivse muutuse kohta täpsemini Huumo 2007; Pajusalu, Tragel 2007; Norvik, Prillop 2017).

(22) jäìj $\mathrm{e}^{\mathrm{t}}$ timầ segeh̆hest

jää.PST.3sG tema pime.TRA

'Tema jäi pimedaks' (lutsi, EM IX: 125)

(23) jǟkā tervehēks

jää.IMP.2SG terve.TRA

'jääge terveks' (isuri, Nirvi 1971: 117)

Tabelist 3 selgub, et muutuse väljendamisel on tulemusseisundi markeerimine translatiiviga ootuspärasem vadja, isuri ja lutsi keeles. Kui võtta arvesse ka liivi keele kohta saadud tulemused, mis näitavad, et liivi keele kõige tüüpilisem muutusverb iedõ 'jääda' esineb ülekaalukalt translatiiviga konstruktsioonis, samuti kasutatakse selles sageli verbi $s \bar{\partial} d \tilde{o}$ 'saada' (Norvik 2014a: 135), siis võib muutuse markeerimist translatiiviga pidada 
iseloomulikuks kogu läänemeresoome lõunarühma keeltele, aga ka soome ja isuri keelele. Seevastu vepsa, lüüdi ja Valdai karjala keeles saab muutuse väljendamist seostada ennekõike nominatiivse tulemusseisundiga (vt järgmisest osast).

\subsubsection{Nominatiivne tulemusseisund}

Tabel 4. Muutusverbide esinemus normaallauses struktuuriga $\mathrm{NP}_{\text {Nom }} \mathrm{V}$ AdjP/NP $\mathrm{Nom}_{\text {N }}$

\begin{tabular}{|l|c|c|c|c|c|c|c|}
\hline Verb/Keel & isuri & lutsi & lüüdi & V. karj & vadja & vepsa & Kokku \\
\hline JÄÄDA & & 1 & 1 & & & & $\mathbf{2}$ \\
\hline SAADA & & 32 & & & & & $\mathbf{3 2}$ \\
\hline LEEDA & 3 & & 12 & 35 & 9 & 3 & $\mathbf{6 2}$ \\
\hline SÜNDIDA & & & 8 & 3 & & & $\mathbf{1 1}$ \\
\hline TULLA & 10 & & & & 7 & & $\mathbf{1 7}$ \\
\hline TEHA & & & & & & 20 & $\mathbf{2 0}$ \\
\hline Kokku & $\mathbf{1 3}$ & $\mathbf{3 3}$ & $\mathbf{2 1}$ & $\mathbf{3 8}$ & $\mathbf{1 6}$ & $\mathbf{2 3}$ & $\mathbf{1 4 4}$ \\
\hline
\end{tabular}

Siinse tüübi alla on paigutatud juhud, kus tulemusseisund on markeerimata (vt 24). Samuti kuuluvad siia aluseta laused, kus nominatiivne öeldistäide iseloomustab olukorra muutust mingis kohas või ajas (25).

(24) d'äin mińä tühd' miež jää.PST.1SG mina vaene mees 'Mina jäin vaeseks meheks' (põhjalüüdi, Kujola 1944: 31)

(25) homendez ańi viлu teǵhe värāš hommikul väga külm tege.PST.REFL.3sG väljas 'Hommikul läks väljas nii külmaks' (lõunavepsa, Kettunen 1920: 38)

Markeerimata konstruktsioon ei seostu siiski üksnes muutusega. Nimelt on eriti olevikuvormis verbi korral ootuspärane muutuse põimumine tulevikus olema saamisega, mil tulevikuline tõlgendus on rohkem esiplaanil (vt näiteid 26-28). Näiteks lause (27) on öeldud kontekstis, kus tutvustati Pühajärvi nime saamislugu, millega seostub selle nime kandmine pärast saamist. Kui aga öeldistäide on komparatiivivormis (29), kerkib esile ikkagi muutuse tõlgendus, täpsemini järkjärguline muutus. 
(26) timä sâ ołłe kuningas̀

tema saa õlg.GEN kuningas

'Tema saab olema õlekuningas' (lutsi, EM IX: 195)

(27) tämä rod'i Pühäjärvi

see sündi.3sg Pühajärvi

'See saab olema Pühajärvi' (kesklüüdi, Norvik 2012)

(28) siлоi lińńep hüvä

siis lee.3sG hea

'Siis saab olema hea' (keskvepsa, NVM 1935: 78)

(29) jo tuep pimmiäpi i pimmiäpi

juba tule.3sg pime.comp ja pime.comP

'Juba läheb pimedamaks ja pimedamaks' (läänevadja, Ariste 1982: 72)

Muutuse tõlgendus osutus ühemõtteliseks ennekõike minevikuvormi sisaldavate näidete korral, kuigi ka laiem kontekst toetas üldjuhul muutuse tõlgendust. Näiteks vepsa TEHA oli 21 juhul 23st tarvitusel minevikuvormis ja seostatav muutuse väljendamisega (nt 25), samas kui kõik vepsa LEEDA näited olid vaid olevikuvormis, väljendades uue olukorra kehtimist tulevikus, kuid vähemalt taustal ka muutust (28). Seega saab verbe TEHA ja LEEDA seostada kindla ajasuhtega.

Erinevalt vepsa keelest on Valdai karjala LEEDA tarvitusel nii mineviku- kui ka olevikuvormis, väljendades nii muutust minevikus (30) kui ka olema saamist tulevikulises lauses (31). Samuti leidub lutsi SAADA, kesklüüdi SÜNDIDA ja põhjalüüdi LEEDA puhul mõlemat kasutust. Nimetatud verbid eristuvadki oma üldise tähenduse poolest, mistõttu võib neid tõlgendada nii poolkopulatiivsete kui ka tulevikukoopulatena (vt ka Norvik 2020).

$$
\begin{aligned}
&(30=7) \text { mie lieńīn } \\
& \text { mina lee.PST.1SG } \text { rase } \\
& \text { 'Ma jäin rasedaks' (Valdai karjala, Palmeos 1962: 84) }
\end{aligned}
$$

(31) šie lienet ožakaš sina lee.2sG õnnelik

'Sina saad olema õnnelik' (Valdai karjala, Palmeos 1962: 161)

Nagu ilmneb, tuleb vaatlusaluse konstruktsiooni kohta enim näiteid Valdai karjala, lutsi, vepsa ja lüüdi keelest. Valdai karjala, vepsa ja lüüdi osutusid ka keelteks, kus sihi markeerimine translatiiviga on harv (vt tabelit 3). 
On võimalik, et vähemalt osaliselt on see tingitud kontaktkeelte mõjust. Näiteks vene stat' 'saada' korral oleneb sihi markeerimine nimisõnast: substantiiv on alati markeeritud (32), adjektiivide korral esineb varieerumist (Timberlake 2004: 286). Samas läti tüüpilise muutusverbi $k l \grave{u} t$ 'saada' puhul on tulemusseisund alati markeerimata, kui seda verbi kasutatakse koos adjektiiviga (LVG 2013: 638). Nii nagu leiab idapoolsetest läänemeresoome keeltest juhte, kus muutuse tähenduses on substantiiv markeerimata (33, vrd 32), leiab ka lutsi keelest näiteid, kus tulemusseisundit väljendav adjektiiv on kord markeeritud (22), kord markeerimata (34). See, millised seaduspärasused välja joonistuvad, vajab siiski edasist uurimist.

(32) On stal izvestnym teatral'nym kritikom tema.m saa.PST.M kuulus.INS.M teatri.INS.M kriitik.INS.M 'Temast sai kuulus teatrikriitik' (vene, Timberlake 2004: 286)

(33) Hän rodiheze vratsa tema sündi.REFL.3sG arst 'Temast sai arst' (kesklüüdi, Norvik 2012)

(34) mak̆kał eǹdzaba? sat maga.2PL õnnis.COMP.PL saa.2PL 'magate, saate õndsamaks' (lutsi, EM IX: 152)

Tulemusseisundi laialdasemat kasutust võib aga seostada ka arenguteega poolkoopula $\rightarrow$ tulevikukoopula, sest just markeerimata vorm näikse kaasa aitavat tulevikuseisundile, kus muutuse väljendamine jääb tagaplaanile (vt 26 ja 31). Sellele, et sihi markeerimine võiks pigem tõsta esile just muutuse, leiab kinnitust vene keelest. Nimelt on väidetud, et vene byt' 'olla' saab muutuse tähenduse ehk väljendab ennekõike seisundi lõppemist, kehtima hakkamist nendel juhtudel, mil komplement on markeeritud (nt 35) (Timberlake 2004: 286; Clancy 2010: 98).

(35) $\mathrm{V}$ ljuboj kompanii budet želannym gostem ... PREP iga.LOC kompanii.LOC olema saa.3sG soovitud.INs külaline.INS '(Ta) saab igas kompaniis olema soovitud külaline ...' (Clancy 2010: 98)

Materjali hulka sattus ka paar sellist näidet, mida saab ennekõike seostada millegi tekkimisega (vt ka osad 4.2 ja 4.3). Näiteks lause (36) puhul ei saa postuleerida seisundit 1, kuna referenti enne selle tekkimist polnudki (st kui leivad valmis said, olidki need kohe pahad). Seda on näidanud ka 
Erelt (2005: 23) lause Raamat tuli hea näitel. Eesti ja liivi keelest leidub kõnealuses konstruktsioonis üksikuid näiteid ka JÄÄDA-verbiga (vt Norvik, Prillop 2017). Teistest läänemeresoome keeltest kogutud valimi hulka selliseid JÄÄDA-verbi sisaldavaid näiteid ei sattunud.

(36) leivät tulivat pahad

leib.PL tule.PST.3PL halb.PL

'Leivad tulid pahad' (vadja, Ariste 1962: 65)

Seega kuulub siinsesse tüüpi näiteid, mis väljendavad esmajärjekorras muutust, kuid on ka neid, kus muutuse väljendamine põimub tulevikus olema saamisega. Lisaks võidakse väljendada hoopis millegi tekkimist.

\subsubsection{Kohakäände või adverbiga tähistatud tulemusseisund}

Tabel 5. Muutusverbide esinemus normaallauses struktuuriga $\mathrm{NP}_{\text {Nom }} \mathrm{V}$ AdvP

\begin{tabular}{|l|c|c|c|c|c|c|c|}
\hline Verb/Keel & isuri & lutsi & lüüdi & V. karj & vadja & vepsa & Kokku \\
\hline JÄÄDA & 2 & 1 & & 2 & 5 & 1 & $\mathbf{1 1}$ \\
\hline SAADA & 2 & 2 & & & & & $\mathbf{4}$ \\
\hline LEEDA & 2 & & 2 & 9 & 3 & 3 & $\mathbf{1 9}$ \\
\hline SÜNDIDA & & & 1 & & & & $\mathbf{1}$ \\
\hline TULLA & 2 & & & & 2 & & $\mathbf{4}$ \\
\hline MINNA & 7 & 2 & & & & & $\mathbf{9}$ \\
\hline TEHA & & & & & & 1 & $\mathbf{1}$ \\
\hline Kokku & $\mathbf{1 5}$ & $\mathbf{5}$ & $\mathbf{3}$ & $\mathbf{1 1}$ & $\mathbf{1 0}$ & $\mathbf{5}$ & $\mathbf{4 9}$ \\
\hline
\end{tabular}

Siinsesse tüüpi on paigutatud näited, kus tulemusseisund on väljendatud adverbiga (37 ja 38). Esindatud on nii muutuse kui ka tulevikus olema saamise väljendamine, kusjuures LEEDA osutus selles konstruktsioonis kõige sagedasemaks verbiks (19 näidet 39st).

(37) jäid ello veel jää.PST.3PL elu.ILL veel 'jäid ellu veel' (läänevadja, Ariste 1982: 70) 
(38) drocona rušow, liew valmis

kartulipuder pruunistu.3sg lee.3sg valmis

'Kartulipuder pruunistub, saab valmis'(Valdai karjala, Palmeos 1962: 94)

Nende seas on ka keeliti korduvaid näiteid, nagu 'ellu/hinge jääda' (nt 37), 'valmis saada' (nt 38). Kui aga minevikulises lauses on kasutusel JÄÄDA ja SAADA, siis tulevikulistes näidetes esineb üldiselt LEEDA, kui keeles on vastav verb kasutusel (v.a lutsi keeles).

\subsubsection{Verbivalik normaallause struktuuritüüpides}

Kui võrrelda verbide esinemist normaallause tüüpide kaupa ühe keele piires, tundub olevat võimalik väita, et varieeruvust on vähem idapoolsetes läänemeresoome keeltes (Valdai karjala, vepsa ja lüüdi keeles), kus esinebki vaid mõni verb peale LEEDA ja üldise muutusverbi (juhul kui üldine muutusverb on muu kui LEEDA). Siiski võib märgata ka leksikaalsest tähendusest tulenevat verbivalikut. Näiteks saab JÄÄDA näiteid eri keeltest seostada ennekõike negatiivse tähendusega, vrd nt 'orvuks/vanaks/ vaeseks/nartsuks jääda' (vt ka Pajusalu, Tragel 2007). Üksnes lutsi keelest tuli vastupidine näide: rikkaks saamist tähistati fraasiga 'rikkaks jääda'. See võib aga olla läti mõju, kuna ka läti keeles on palikt 'jääda' suulises keeles üldise tähendusega (vt osast 2). MINNA puhul aga kordus ühend 'hulluks minna', samuti esines 'punaseks minna' ja 'katki minna'. Kui 'hulluks minna' ja 'punaseks minna' seostuvad seisundi intensiivistumisega, siis 'katki minna' võiks paigutada negatiivse muutuse alla (vrd osa 2).

\subsection{Tulemuslause}

Tabel 6. Muutusverbide esinemus tulemuslauses struktuuriga $\mathrm{NP}_{\mathrm{Ela}} \mathrm{V} \mathrm{NP} \mathrm{Nom}_{\text {Nom }}$

\begin{tabular}{|l|c|c|c|c|c|c|c|}
\hline Verb/Keel & isuri & lutsi & lüüdi & V. karj & vadja & vepsa & Kokku \\
\hline SAADA & & 6 & & & & & $\mathbf{6}$ \\
\hline LEEDA & & & 2 & 1 & 1 & 3 & $\mathbf{7}$ \\
\hline TULLA & 3 & & 2 & & 2 & & $\mathbf{7}$ \\
\hline MINNA & & & 1 & & & & $\mathbf{1}$ \\
\hline TEHA & & & & & & 2 & $\mathbf{2}$ \\
\hline Kokku & $\mathbf{3}$ & $\mathbf{6}$ & $\mathbf{5}$ & $\mathbf{1}$ & $\mathbf{3}$ & $\mathbf{5}$ & $\mathbf{2 3}$ \\
\hline
\end{tabular}


Siinsesse tüüpi paigutuvad konstruktsioonid, kus elatiivi käändega on markeeritud lähe (vt 39-41). Nagu tabelist 6 ilmneb, osutus kõnealune tüüp kõigis keeltes marginaalseks. Tulemuskonstruktsiooni marginaalsuse kohta leiab tõendeid teistestki läänemeresoome keeltest. Näiteks liivi iedõ 'jääda', sōdõ 'saada' ja līdõ 'leeda' võrdlusest selgus, et tulemuskonstruktsioonis esineb vaid sōdõ, kusjuures 150 sōdõ-näite hulgas on vaid 4 kasutusjuhtu (vt Norvik 2014a: 124). Kuigi Tiit-Rein Viitso (2008: 344) on liivi keele tulemuslauset seostanud ka verbiga lìdõ 'leeda', pole tekstidest õnnestunud selle kohta näiteid leida (Norvik 2014a: 124). Soome keeles võib tänapäeval elatiivset konstruktsiooni pidada küll kõige tüüpilisemaks muutuskonstruktsiooniks, kuid vana kirjakeele andmed on näidanud, et tegu on võrdlemisi uue nähtusega (vt Jokela, Nummila 2015). Samuti näitavad eesti vana kirjakeele andmed tulemuskonstruktsiooni hilist arengut (Tragel, Habicht 2012). Lähtekohta märkivate konstruktsioonide vähesust allikmaterjali hulgas on näidatud teistegi konstruktsioonide korral (mast-vormi esinemuse kohta eesti keeles vt Pajusalu, Orav 2008).

(39) kõikka paganapassa tütössä tuli

kõige kuri.COMP.ELA tüdruk.ELA tule.PST.3SG

kõikka parepi tüttö

kõige parem tüdruk

'Kõige kurjemast türdukust tuli kõige parem tüdruk' (läänevadja, Ariste 1962: 80)

(40) must sâ hel̆le kan̆nel'

mina.ELA saa hele kannel

'Minust saab hele kannel' (lutsi, EM IX: 183)

(41) ŕeb ${ }^{u}$ oin nahkàs tuл $\overline{0}^{\underline{u}} / \ldots /$ hüvä vorot'ńik

rebane.GEN nahk.ELA tule.3sG hea kaelus

'Rebase nahast tuleb /.../ hea kaelus' (põhjalüüdi, LK 1934: 10)

Nende harvade näidete puhul, mis andmestikus esinesid, võib siiski väita, et enamasti sisaldus konstruktsioonis vastavale keelele omane muutusverb. Vepsa keeles oli selleks TEHA ja vadja keeles TULLA (39), seevastu lutsi keelest tuli näiteid üksnes SAADA kohta (40), mis on tavaline muutusverb ka eesti keeles. Samuti olid vadja ja lutsi keele lisanäidete hulgas tavalisimad needsamad muutusverbid, vastavalt TULLA ja SAADA. LEEDA esines vaadeldavas konstruktsioonis aga koguni neljas keeles: vadja, vepsa, lüüdi ja Valdai karjala keeles. Kõigil juhtudel oli tegu LEEDA 
olevikuvormiga, mis andis tulevikutõlgenduse ning millest osaliselt võis lähtuda ka verbivalik. Samas tuli eriti just neil juhtudel hästi esile tihe seos muutumistähendusega, sest erinevalt näiteks olemasolulausest, kus muutuse tulemusel alles miskit tekkib (vt osast 4.4), on lähet märkivates lausetes eksplitsiitselt väljendatud osaline, kes teeb mingil viisil läbi muutuse (nt kivi $\rightarrow$ liiv lauses 42).

(42) tästä kiveštä liew pesku

see.Ela kivi.ELA lee.3sg liiv

'Sellest kivist saab liiv' (Valdai karjala, Palmeos 1962: 108)

Lüüdi keeles oli varieeruvust kõige enam: LEEDA kõrval esines ka TULLA, mis muidu osutus lüüdi keeles marginaalseks (terves andmestikus oli kokku kolm näidet, neist kaks tulemuslauses). Kahe näitega oli esindatud lähteä 'minna', millest teine näide pärineb lisanäidete hulgast, mistõttu ei kajastu see tabelis 6 (vt 43). Sage muutusverb SÜNDIDA ei esinenud lüüdi keeles kõnealuses konstruktsioonis kordagi. Seda võib põhjendada asjaoluga, et kõik tulemuskonstruktsiooni kohta leidunud näited olid põhjalüüdist, kus SÜNDIDA ei olegi ootuspärane (vt ka Kehayov jt 2013).

(43) maimaz lähtöu rok hüvä

ahvenapoeg.PL.ELA mine.3sg supp hea

'ahvenapoegadest tuleb hea supp' (põhjalüüdi, Kujola 1944)

Nagu tabelist 6 ilmneb, ei esinenud vaadeldavas konstruktsioonis kordagi ka verb JÄÄDA. Küll aga leidus eesti ja liivi keele JÄÄDA kohta tehtud võrdlevas uurimuses mõni näide, kus elatiiv märkis millegi põhjust või mingit suuremat entiteeti, millest osa eemaldatakse (44) (Norvik, Prillop 2017: 253-254). Sellist kasutust on kirjeldatud ka soome keele puhul (vt Huumo 2007). Mitteesinemuse põhjus võib osalt peituda selles, et lähe pole alati eksplitsiitselt väljendatud, kuigi oleks kohati juurdemõeldav. Näiteks lausesse (45) võiks lisada isiku, kellest laps jäi järele. Praegusel juhul liigitati seda tüüpi näited olemasolukonstruktsiooni alla. Sellised juhud osutavad tulemus- ja olemasolukonstruktsiooni vahelisele seosele.

(44) Majast jäid mustad seinad (enTenTen[www.naisteleht.ee], viidatud Norvik, Prillop 2017: 254 järgi)

(45) ühs lahs jäi

üks laps jää.PST.3sG

'Üks laps jäi (järele)' (läänevadja, Ariste 1982: 48) 
Soome keele grammatikas (VISK § 904) on lähet markeeriva konstruktsiooni kohta mainitud, et võimalik on ka olukord, kus muutust tegelikult ei toimu (46). Siinse artikli tarvis kogutud läänemeresoome materjalis oli selliseid näiteid ennekõike normaallausekujuliste juhtude hulgas (vt täpsemini osast 4.1); normaallausekujuline on ka siin esitatud eestikeelne tõlge.

(46) Leivonnaisista tuli suussasulavia

küpsetis.PL.ELA tule.PST.3SG suussulav.PL.PRT

'Küpsetised tulid suussulavad' (soome, VISK § 904)

Seega, vähesed näited ja mitte alati kõige ühesem viis väljendada muutust lubavad tõdeda, et tulemuskonstruktsiooni abil väljendatakse vaadeldud keeltes muutust pigem harva.

\subsection{Kogejalause}

Tabel 7. Muutusverbide esinemus kogejalauses struktuuriga $\mathrm{NP}_{\text {Ade }} \mathrm{V}$ AdjP/NP $/ \mathrm{NP}_{\text {Nom }}$

\begin{tabular}{|l|c|c|c|c|c|c|c|}
\hline Verb/Keel & isuri & lutsi & lüüdi & V. karj & vadja & vepsa & Kokku \\
\hline SAADA & & 7 & & & & & $\mathbf{7}$ \\
\hline LEEDA & & & 7 & 13 & & 1 & $\mathbf{2 1}$ \\
\hline SÜNDIDA & & & 7 & 1 & & & $\mathbf{8}$ \\
\hline TULLA & 5 & & & & 5 & & $\mathbf{1 0}$ \\
\hline TEHA & & & & & & 9 & $\mathbf{9}$ \\
\hline Kokku & $\mathbf{5}$ & $\mathbf{7}$ & $\mathbf{1 4}$ & $\mathbf{1 4}$ & $\mathbf{5}$ & $\mathbf{1 0}$ & $\mathbf{5 5}$ \\
\hline
\end{tabular}

Kogejalauses on kogeja vormistatud kohakäändega (47) või liivi keeles ka daativiga (48). Poolkopulatiivse verbi esinemisel kogejalauses on tegu seisundimuutusega.

(47) hӓлле rod'ī d'üged

'Tal hakkas raske' (põhjalüüdi, Kujola 1944: 361)

(48) tä'mmõn um iend irm

ta.DAT ole.3sG jää.APP hirm

'Tal hakkas hirm' (liivi, Mägiste 1964: 24) 
Kogejalause tõuseb esile selle poolest, et igas keeles esineb selles konstruktsioonis vaid 1-2 verbi. Sealjuures on märkimisväärne asjaolu, et tegu on nendesamade verbidega, mis vaatlusalustes keeltes on kasutusel kõige üldisemate muutusverbidena või ka tulevikukoopulana (vt ka Norvik 2020). Lisakinnitust annab liivi keel, kus kogejalauses väljendatakse seisundimuutust üldise muutusverbi JÄÄDA abil (48). Tabelist 7 ilmneb, et vastavat kasutust ei leidu ühestki teisest uuritud keelest. Samuti ei ole selline seisundimuutuse väljendamine omane ei eesti ega soome keelele. Nagu lausete (47-50) tõlgetest näha, on eesti keeles seisundimuutuse märkimisel ootuspärane hoopis hakkama-verb. Kuivõrd aga inhoatiivne (algust märkiv) verb on võimalik teistes keeltes, vajab omaette tähelepanu.

(49) mamale žäl' poigut t'eǵhe ema.ALL kahju poeg.PRT tege.PST.REFL.3sG

'Emal hakkas pojast kahju' (keskvepsa, NVM 1935: 30)

(50) mièl sâ $\mid$ mẹlembil l'ämóńi

meie.ADE saa mõlemad.ADE soe

'Meil mõlemal hakkas soe' (lutsi, EM IX: 179)

Vepsa ja Valdai karjala keeles, kus kogejalauses sisaldub enam kui üks verb, on siiski põhjust seisundimuutust seostada vastavalt TEHA- ja LEEDA-verbiga, sest tabelis esitatud üksikud näited on võrdlemisi piiripealsed ning ei viita ilmtingimata üldse seisundimuutusele. Mõlemas näites on subjektiks küsiv-siduv asesõna (vt 51).

(51) mìdä šiuлa $\quad$ rod'ih

mis.PRT sina.ADE/ALL sündi.PST.REFL.3SG

'Mis sul hakkas?' (Valdai karjala, Palmeos 1962: 137)

Lüüdi 14 näitest 12 pärinevad põhjalüüdi ja 2 kesklüüdi aladelt. On huvitav märkida, et põhjalüüdi 12 näitest 6 sisaldavad verbi SÜNDIDA, kuigi põhjalüüdi ala võiks pidada hoopis LEEDA-alaks (vt Kehayov jt 2013). Kõik andmestikus leiduvad põhjalüüdi näited pärinevad aga Ojansuu jt koostatud kogumikust (LK 1934), mistõttu ei luba need midagi öelda võimalike kasutusmuutuste kohta. Kaks kesklüüdi näidet (üks SÜNDIDA, teine LEEDA kohta) on üles kirjutatud 2012. aastal, kusjuures verbi SÜNDIDA sisaldav näide pärineb kesklüüdi tuumalalt, verbi LEEDA sisaldav näide aga kesklüüdi põhjaosast, mida on samuti põhjust lugeda LEEDAalaks (vt Kehayov jt 2013). Kuna LEEDA tundub vähemalt kesklüüdi 
tuumalal olevat tänapäevaks tagaplaanile jäänud, on alust arvata, et selles piirkonnas varieerumist ei esine.

Lisanäited lutsi, vadja ja vepsa keelest kinnitavad ülal kirjeldatut. Põhjalüüdist kogutud lisanäidete hulgas leidub siiski kaks TULLA-verbi sisaldavat muutuskonstruktsiooni (nt hüvä tuli 'hakkas hea'). Seega paistab, et 20. sajandi keskpaiga põhjalüüdi keeles võib kogejalause korral märgata enim varieerumist.

\subsection{Olemasolulause}

Tabel 8. Muutusverbide esinemus olemasolulauses struktuuriga $(\mathrm{AdvP}) \mathrm{V} \mathrm{NP}_{\mathrm{Nom} / \mathrm{Prt}}$

\begin{tabular}{|l|c|c|c|c|c|c|c|}
\hline Verb/Keel & isuri & lutsi & lüüdi & V. karj & vadja & vepsa & Kokku \\
\hline JÄÄDA & & 5 & & 1 & 4 & & $\mathbf{1 0}$ \\
\hline SAADA & 1 & 21 & & & & & $\mathbf{2 2}$ \\
\hline LEEDA & 8 & & 20 & 23 & 14 & 10 & $\mathbf{7 5}$ \\
\hline SÜNDIDA & 1 & & 20 & 2 & & & $\mathbf{2 3}$ \\
\hline TULLA & 12 & 1 & & & 15 & 9 & $\mathbf{3 7}$ \\
\hline TEHA & & & & & & 14 & $\mathbf{1 4}$ \\
\hline Kokku & $\mathbf{2 2}$ & $\mathbf{2 7}$ & $\mathbf{4 0}$ & $\mathbf{2 6}$ & $\mathbf{3 3}$ & $\mathbf{3 3}$ & $\mathbf{1 8 1}$ \\
\hline
\end{tabular}

Olemasolukonstruktsiooni moodustavad verb ja NP-kujuline subjekt (vt 52), võib esineda ka koha- või ajamäärus (53). Kui kopulatiivne OLLA väljendab olukorda mingis kohas või ka ajas, siis poolkopulatiivsete verbide korral on üldjuhul tegu mingi olukorra kättejõudmise või tekkimisega (52-55). Märkimisväärse hulga (umbes 1/4) moodustavad andmestikus juhud, millega väljendati muutust ilmastikuoludes, öö ja päeva vaheldumises jms (vt 52 ja 53). Näiteks esines sellises kasutuses 14st vepsa TEHA-verbist 9.

(52) tul'i

tọińe süügüz

tule.PST.3sG teine sügis

'Tuli teine sügis' (keskvepsa, OVR 1969: 23)

(53)
pert' iš t'eǵîhe vouget_päif jo
tare.INE tege.PST.REFL.3SG valge päev juba
'Tares läks juba valgeks' (keskvepsa, NVM 1935: 28) 
(54) liettih kолhоzat

lee.PST.3PL kolhoos.PL

'Tekkisid kolhoosid' (Valdai karjala, Palmeos 1962: 85)

(55) sīh rod'i kirikkö

siia sündi.PST.REFL.3sG kirik

'Siia tuleb kirik' (kesklüüdi, Norvik 2012)

Tabelist 8 torkab silma asjaolu, et olemasolulausete hulk on võrdlemisi suur - 181 ehk peaaegu 1/3 näidetest. Lisaks võib märgata, et võimalike verbide hulk selles konstruktsioonis on tavapärasest suurem: keskmiselt kolm analüüsitud verbidest esines olemasolukonstruktsioonis. Sealjuures leidub verbe, mida saabki seostada vaid kõnealuse konstruktsiooniga. Näiteks vepsa andmestikus oli kokku üheksa TULLA-verbi, mis kõik esinesid olemasolulauses, kusjuures kaheksa neist leidus ilmastikunähtuste / öö ja päeva vaheldumise kirjelduses. Samuti oli lutsi keele ainus TULLA-verbi sisaldav näide seotud just sellesama kasutusalaga ( $t u \bar{I}^{\prime}$ hedak 'tuli õhtu').

JÄÄDA-konstruktsioonid on huvitavad selle poolest, et näited, mis valimi hulka sattusid, olid võrdlemisi sarnased, väljendades olukorda, kus midagi jääb alles/järele (56). Liivi keelest, kus kõnealune verb toimib üldise muutusverbina, leiab muu hulgas tekkimise tähenduse (57). Osaliselt avaldub seesuguses verbi JÄÄDA tarvituses läti mõju (vt rohkem Norvik, Prillop 2017), mis võiks seletada ka seda, miks ei õnnestunud muudest läänemeresoome keeltest leida samasuguse kasutuse kohta näiteid.

(56) da kopēk лаske ïäb

ja kopikas las.IMP.2PL jää.3sG

'Ja las kopikas jääb' (lõunavepsa, Kettunen 1920: 24)

(57) sei toiz umārz jerā

söö.PST.3SG teine.GEN õun.GEN ära

ei toi sộra pẳ'z

jää.PST.3sG teine sarv pea.ILL

'Sõi teise õuna ära, tekkis teine sarv pähe' (liivi, Setälä 1953: 124)

Kõige enam näiteid on LEEDA kohta - 75/181, kusjuures esindatud on kõik keeled, kus LEEDA on võimalik. Enamiku moodustavad juhud, mis ei väljenda mitte niivõrd muutust, kuivõrd tulevikus olema saamist (vt 58, kus tegevuse tulemusena alles midagi tekkib). Eitusvormi korral väljendatakse LEEDA abil seda, et miski ei hakka eksisteerima (59) või lõpetab eksisteerimise (60). Siinkohal võib tõmmata paralleele vene 
verbiga stat' 'saama', mida kasutatakse samuti tähenduses 'surema' (vrd 61). Nagu selgub, on verbil stat' eksistentsiaallauses ootuspärane just muutuse tõlgendus (Timberlake 2004: 304-305).

(58) liew šūíi kobra

lee.3sG suur peotäis

'[Hakkan lõikama siia sõrmede vahele, nüüd siia,] saab olema suur peotäis' (Valdai karjala, Palmeos 1962: 101)

(59) eihä tō da $\overline{0} \quad$ enne ollud /.../ eigä le्र̄ne

NEG too.PRT be.CNG enne ole.APP NEG lee.POT.CNG

'seda pole enne olnud /.../ ega saa ka olema' (isuri, Nirvi 1971: 263)

(60) ei liennenu hebod

ei lee.POT.APP hobune.PRT

'ei jäänud hobust (= suri)' (põhjalüüdi, LK 1934: 73)

(61) Vani ne stalo

Vanja.GEN NEG saa.PST.N

'Vanjat ei jäänud (= suri)' (vene, Timberlake 2004: 305)

Sellistes keeltes nagu vadja, isuri ja vepsa, kus LEEDA on võimalik vaid olevikuvormis, seostus LEEDA enamasti tulevikuga, kuid tulevikus olema saamise kõrval võis sealjuures esil olla ka kahtluse väljendamine. Nii esinesid kõik 14 näidet vepsa TEHA-verbi kohta eranditult minevikuvormis, väljendades minevikulist sündmust, kuid 10 LEEDA-näidet olid seotud tulevikulise sündmusega.

MINNA kohta ei sattunud andmestikku küll ühtegi näidet (vt tabelit 8), kuid vadja keelest kogutud lisanäidete hulgas leidus siiski kolm (vt 62). Kõik need pärinesid VKSist ning olid üles kirjutatud idavadjast.

(62) sis läheв kangaz

siis mine.3sG kangas

'siis tuleb (sellest) kangas' (idavadja, VKS) 


\subsection{Omajalause}

Tabel 9. Muutusverbide esinemus omajalauses struktuuriga $\mathrm{NP}_{\text {Ade/All }} \mathrm{V} \mathrm{NP}_{\text {Nom/Prt }}$

\begin{tabular}{|l|c|c|c|c|c|c|c|}
\hline Verb/Keel & isuri & lutsi & lüüdi & V. karj & vadja & vepsa & Kokku \\
\hline JÄÄDA & 1 & & & & 5 & 5 & $\mathbf{1 1}$ \\
\hline SAADA & & 5 & & & & & $\mathbf{5}$ \\
\hline LEEDA & 5 & & 4 & 8 & 2 & 3 & $\mathbf{2 2}$ \\
\hline SÜNDIDA & & & 9 & & & & $\mathbf{9}$ \\
\hline TULLA & & & & & 1 & & $\mathbf{1}$ \\
\hline TEHA & & & & & & 7 & $\mathbf{7}$ \\
\hline Kokku & $\mathbf{6}$ & $\mathbf{5}$ & $\mathbf{1 3}$ & $\mathbf{8}$ & $\mathbf{8}$ & $\mathbf{1 5}$ & $\mathbf{5 5}$ \\
\hline
\end{tabular}

Omajakonstruktsiooni moodustab kohakäändega (liivi keeles daativiga) markeeritud omaja ja üldiselt lause reema osas paiknev nimetava- või osastavakäändeline omatav (vt 63-65). Kui kopulatiivne OLLA märgib staatilist omandisuhet, siis poolkopulatiivse verbi abil väljendatakse muutust omandisuhetes või omatavas (nt selle koguses), samas millestki võidakse ka ilma jääda või miski võidakse enda valdusesse saada, ilma et omatav liiguks ühelt omajalt teisele (63-65).

(63) nōrembał pujał saì tatse pal'l'o noor.COMP.ADE poeg.ADE saa.PST.3SG laps.PL.PRT palju

'Nooremal pojal sai olema palju lapsi' (lutsi, EM IX: 185)

(64) t'eǵhez

meil' leibad enamb

tege.PST.REFL.3SG meie.ADE leib.PL enam

'Meil sai olema rohkem leiba' (keskvepsa, NVM 1935: 34)

(65) tälle eb jäännü ühtä poikaa tema.ALL NEG.3SG jää.APP ükski.PRT poeg.PRT

'Talle ei jäänud ühtki poega' (läänevadja, Ariste 1962: 62)

Nagu näidetest (63)-(65) ja tabelist 9 selgub, kasutatakse keeles levinud üldist muutusverbi, kuid näiteid leidub ka LEEDA ja JÄÄDA tarvituse kohta. LEEDA väljendab olenevalt keelest tulevikulist või ka minevikulist olukorda, kusjuures tuleviku puhul võib tegu olla ka olukorra jätkumisega. Näiteks lause (66) korral on kontekstist võimalik aru saada, et omanikul on lehm ja see jääb talle ka edaspidi. Seega, Valdai karjala keeles on LEEDA võimalik ka juhul, kus eesti keeles on ootuspärane JÄÄDA-verb 
(vrd eestikeelset tõlget). Üldiselt on tulevikuline olukord siiski esitatud sellisena, et seda otseselt ei saa pidada olevikulise olukorra jätkuks (67).

(66) тіила liew lehmä, a maijot häńel'l'ä mina.ADE/ALL lee.3sg lehm, aga piim.PL tema.ADE 'Mulle jääb lehm, aga piim (jääb/läheb/saab) talle' (Valdai karjala, Palmeos 1962: 106)

$\begin{array}{ll}\text { (67) suł̀ sâ hüà̀ jeło } \\ \text { sina.ADE } & \text { saa hea }\end{array}$

'Sul saab hea elu olema' (lutsi, EM IX: 125)

Omajakonstruktsioon on lähedalt seotud olemasolukonstruktsiooniga. Kui lausetest (63)-(67) omaja välja jätta, olekski tegu olemasolukonstruktsiooniga, sh tähenduse poolest - need väljendaksid mingi olukorra kätte jõudmist, tekkimist (vt olemasolulause kohta ka osast 4.4). See asjaolu näitab tihedat seost nende kahe lausetüübi vahel. Omajalauset on soome grammatikas esitatud ka kui olemasolulause alatüüpi (VISK § 895).

\section{Seosed lausetüüpide vahel}

Võttes arvesse osas 4 esitletud tulemusi muutuse väljendamise kohta läänemeresoome keeltes/keelevariantides, on võimalik alltoodud joonise abil kirjeldada eri lausetüüpide vahelisi seoseid. Joonisel esinevad näited pärinevad siinsest tööst (sulgudes olev number viitab töös esinenud näitenumbrile).

Kõige keskmesse võib paigutada olemasolulause, mis poolkopulatiivse verbi korral esitleb millegi tekkimist või ilmumist aega või ruumi (52). Seda kasutust oli andmestikus märgata kõige enam (vt ka lisast tabeleid 11 ja 12). Lisaks osutus olemasolulause kohati ainsaks konstruktsiooniks, kus mõni uuritud verb üldse esines. Näiteks nii vepsa kui ka lutsi keeles leidus verbi TULLA üksnes selles kasutuses, kuigi samas konstruktsioonis on tarvitusel ka keelele omane üldise tähendusega muutusverb - vastavalt TEHA ja SAADA. Ainus isuri keelest leitud juht SÜNDIDA kohta esines samuti olemasolulauses. Kõik see osutab võimalusele, et just olemasolulausest saab alguse poolkopulatiivse verbi levik teistesse konstruktsioonidesse.

Teatavate üleminekujuhtumitena võib käsitleda normaallausekujulisi näiteid, millega väljendatakse ennekõike tekkimist, mitte referendi 


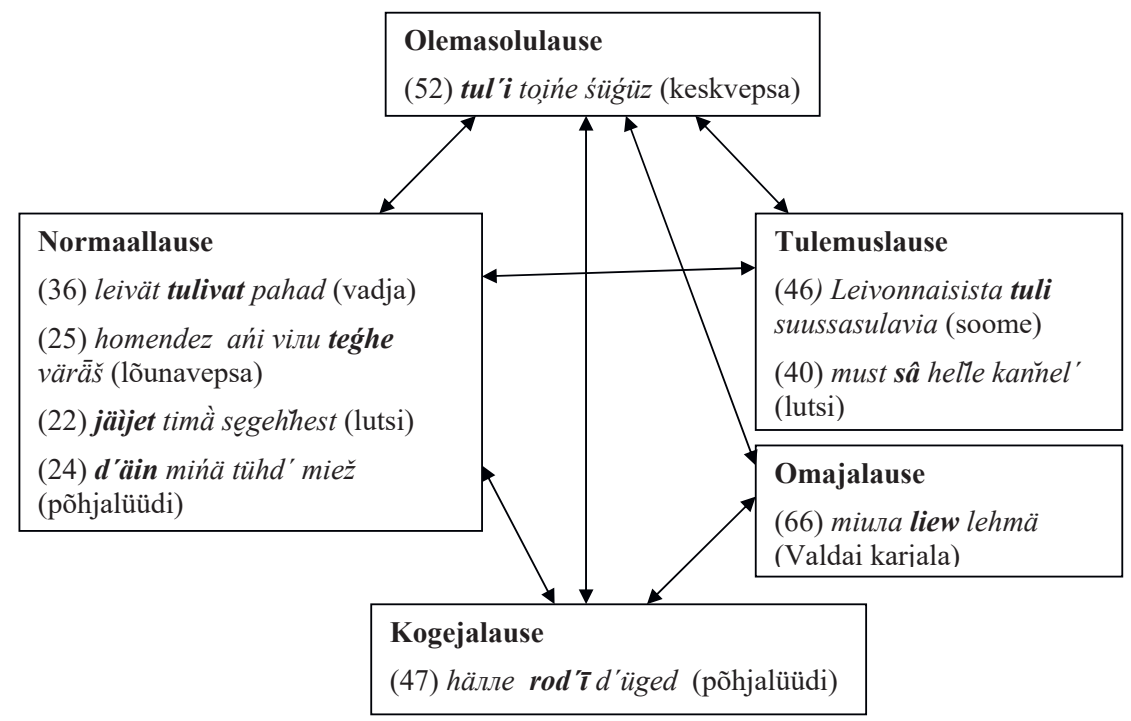

Joonis. Seosed lausetüüpide vahel

muutust (vt 36, mis iseloomustab olukorda, kus leiba enne selle valmimist ei olnudki). Sealt on siiski lühike samm näideteni, millega väljendatakse juba muutust seisund $1 \rightarrow$ seisund 2 . Nende hulgas on nii juhte, kus alus puudub (25), kui ka neid, kus alus on eksplitsiitselt väljendatud ning tulemusseisund on märgitud nominatiivi (24), translatiivi (22) või seisundimäärusega. Siinkohal eristusid idapoolsed läänemeresoome keeled, aga ka lutsi keel, kus tulemusseisund on tüüpiliselt väljendatud nominatiiviga. Osalt võib tegu olla sellega, et kontaktkeeltes ei ole muutuse väljendamisel sihi markeerimine käändega alati vajalik (nt adjektiivide korral), teisalt aga võib selles näha arengut poolkoopula $\rightarrow$ tulevikukoopula, sest muutuse tähendus jääb kergemini tagaplaanile siis, kui siht on markeerimata.

Sarnaselt normaallausega leidub ka tulemuslausete seas näiteid, millega väljendatakse pigem millegi teket kui muutust (46). Seega ilmneb taas selge seos olemasolulausega. Lähet märkiva osalise väljajätmisel saakski lauset tõlgendada olemasolulausena. Kuigi kõnealune tüüp osutus marginaalseks kõigis läänemeresoome keeltes, oli andmestikus siiski mõningaid näiteid, millega väljendatakse muutust (vt 40). Need osutavad arengule TEKKIMINE $\rightarrow$ MUUTUS, mil muutusele alluja on olemas enne olukorra muutust, mitte ei teki muutuse tulemusel. 
Samuti on olemasolulausel seos omajalause ja kogejalausega (66 ja 47). Taas ilmneb, et kui määrus ära jätta, olekski tegu olemasolulausega (vrd 52). Soome keeles ongi omajalauset nimetatud olemasolulause alatüübiks, eesti keele grammatikas on neid olnud tavaks ka ühe tüübina käsitleda. Kogejalause puhul võib näha seost ka aluseta normaallausega, kuna mõlemas sisaldub omadussõnaline öeldistäide (vrd 47 ja 25). Lisakinnitust olemasolulause, kogejalause ja aluseta normaallause seosele annab asjaolu, et Valdai karjala keeles üsnagi harva esineva SÜNDIDA-verbi kohta tuli näiteid vaid nendest lausetüüpidest. Nii eristub Valdai karjala SÜNDIDA lüüdi SÜNDIDA tarvitusest, sest viimast võib leida enamikust tüüpidest ning verb on üldiselt sage - lüüdis oli 47 esinemust, Valdai karjalas aga 6. Levimus struktuuritüüpides aitabki iga keele puhul välja sõeluda need muutusverbid, mis on kõige üldisema kasutusega.

Kuigi joonisel olevad näited pärinevad eri keeltest ja esindavad eri verbe, annavad lisas toodud tabelid aimu, et ühes keeles on esindatud 3-6 verbi 7 st (vt tabel 10). Analüüsitud struktuuritüüpidest on aga igale keelele tuntud kõik tüübid (vt tabel 11), kuigi eri verbide kaudu. Translatiiviga väljendatud tulemusseisund olenes siiski pigem keelest: idapoolsetes läänemeresoome keeltes oli vaatlusalune struktuuritüüp harv. Kõigis keeltes osutus marginaalseks üksnes normaallausekujuline juht, kus öeldistäide on tähistatud essiiviga.

Mõnevõrra rohkem kõikumist leidus selles, mis verbiga mingit struktuuritüüpi võib seostada (vt tabel 12). Ainus verb, mille puhul olid esindatud kõik tüübid, on LEEDA, kusjuures kokku moodustasid verbi LEEDA sisaldavad näited veidi enam kui 1/3 kogu andmestikust (212 näidet). Järgnesid verbid TULLA (100 näidet) ja SAADA (91 näidet). Kõige vähem oli esindatud MINNA - vaid 22 näidet. Seda võib põhjendada asjaoluga, et erinevalt teistest verbidest pole MINNA üheski keeles kõige tüüpilisem muutumistähendusega verb, samuti pole see kasutusel tulevikukoopulana (vt tabel 1, läänemeresoome keeltele kõige iseloomulikumate verbide tuvastamise kohta vt ka Norvik 2020). 


\section{Kokkuvõte}

Artiklis oli vaatluse all muutuse väljendamine kuues läänemeresoome keele(variandi)s: lutsi, vadja, isuri, lüüdi, vepsa ja Valdai karjala. Igast keelest analüüsiti 100 näidet, mis sisaldasid verbi JÄÄDA, LEEDA, MINNA, SAADA, SÜNDIDA, TEHA ja/või TULLA ning esinesid normaal-, olemasolu-, tulemus-, kogeja- ja/või omajalauses. Leksikaalsete erinevuste analüüsimisel kasutati ka lisanäiteid. Saadud tulemusi kõrvutati varasemate uurimistulemustega muutuse väljendamise kohta eesti, soome ja liivi keeles.

Uurimistulemused näitasid, et poolkoopula tarvitamist uuritud lausetüüpides võib seostada muutuse väljendamisega. Nende seas on nii selliseid juhte, kus muutusele alluja on eksplitsiitselt väljendatud ning teeb läbi muutuse (nt normaal-, tulemuslauses), kuid on ka juhte, millega väljendatakse uue osalise tekkimist (nt olemasolulauses). Poolkoopula kasutus omajalauses väljendab samuti muutust: muutuvad omandisuhted, miski saadakse enda valdusesse või millestki jäädakse ilma.

Lausetüüpide seoste analüüsist selgus, et kuigi iga lausetüübiga võiks seostada mingit prototüüpset kasutust, leidub ka marginaalseid kasutusjuhte, mis annavad aimu seostest/arenguteedest. Nii väljendab poolkoopula olemasolulauses üldiselt tekkimist, kuid sama tähendus võib poolkoopulal olla ka tulemus- ja normaallauses, kuigi enamasti on eriti normaallausetes esil muutuse tähendus, mil entiteet mitte ei teki, vaid teeb läbi muutuse. Tundub siiski, et just olemasolulauset ja sellega seostatavat tekkimise tähendust võib pidada poolkopulatiivse verbi levikul keskseks: need olid ühel või teisel viisil seostatavad kõigi teiste lausetüüpidega, olemasolulausete hulk lõplikus valimis oli kõige suurem (212/600), samas oli ka eri verbide kasutus kõige suurem (keele kohta sageli kolm verbi, vrd kogejalausega, kus esines keele kohta vaid üks-kaks verbi). Mõnes keeles sisaldus uuritav verb üksnes olemasolulauses, nt kõik vepsa TULLA-verbi kasutusjuhud esinesid vaid olemasolulauses.

Lausetüüpide analüüsist nähtus, et osalt sõltub mingi konstruktsiooni esinemine keelest, näiteks tulemusseisundi markeerimine translatiivikäändega osutus harvaks idapoolsetes läänemeresoome keeltes: Valdai karjala, vepsa ja lüüdi keeles on ootuspärane pigem nimetava käände kasutamine. Kuigi osalt võiks sellist eelistust pidada kontaktimõjuliseks, selgus uurimistulemustest, et need keeled ei järgi vene malli täielikult ning 
täpsemate seaduspärasuste väljaselgitamiseks on vaja edasist uurimist. Samas tundus võimalik seostada nimetava käände kasutust edasiarenguga tulevikukoopula suunas. Nimelt lutsi ja Valdai karjala keeles, kus nii muutuse kui ka tuleviku väljendamiseks oli ülekaalukalt esindatud üks verb (Valdai karjalas oli 100 näite seas 90 LEEDA-verbi ja lutsi keeles oli 87 SAADA-verbi), tõusis tulevikuline tõlgendus selgemini esile just näidetes, kus tulemusseisund oli väljendatud nominatiiviga. Ka kontaktkeeltest (nt vene keel) leiab tõestust selle kohta, et muutuse väljendamine on koopula korral esil juhtudel, kui tulemusseisund on markeeritud. Seega, markeerimata tulemusseisund näikse toetavat tõlgendust, kus muutuse väljendamine on pigem tagaplaanil.

Artiklis leidis kinnitust tõsiasi, et iga keeles esinev poolkoopula ei sobi tingimata igasse lausetüüpi igasuguse komplemendiga. Isegi kui keeles oli laialt levinud vaid üks (pool)koopula, polnud uuritud keelte hulgas ühtki keelt, kus poleks esinenud ka mõnd teist vaadeldavatest verbidest. Näiteks Valdai karjala keeles oli 90 LEEDA kõrval kuus näidet SÜNDIDA ja neli näidet JÄÄDA kohta. Kuigi kõigis keeltes tuli esile juhte, kus sarnases kasutuses esines enam kui üks verb (nt vepsa keeles oli tähenduses 'tuli õhtu' kasutusel nii eht teghe kui ka eht tuli), esines näiteid, kus verbivalik näis tulenevat leksikaalsetest kaalutlustest (eriti just JÄÄDA ja MINNA korral). Verbivaliku võib aga tingida ka lausetüüp. Näiteks kogejalauses väljendas seisundimuutust vaid keelele kõige omasem muutusverb. Samuti võis verbivalik olla tingitud ajasuhtest. Nii oli vepsa keeles TEHA ülekaalukalt kasutusel minevikulises muutust märkivas lauses, samas kui LEEDA seostus ennekõike tulevikuga, milles põimuvad tulevikuline ja muutuse tähendus, sageli ka modaalne tähendus.

\section{Lühendid}

1, 2, 3 - isik; ADE - adessiiv; ALL - allatiiv; APP - aktiivi minevikupartitsiip; COMP - komparatiiv; DAT - daativ; GEN - genitiiv; ELA - elatiiv; ESS - essiiv; ILL - illatiiv; IMP - imperatiiv; INE - inessiiv; INS - instrumentaal; M - meessugu, $\mathrm{N}$ - kesksugu, NEG - eitus; PL - mitmus; POT - potentsiaal; PRT - partitiiv; PST minevik; REFL - refleksiiv; SG - ainsus; TRA - translatiiv 


\section{Kirjandus}

Adler, Elna 1968. Vadjalaste endisajast I. Idavadja murdetekste. Tallinn: Eesti NSV Teaduste Akadeemia Keele ja Kirjanduse Instituut.

Ariste, Paul 1962. Vadja muinasjutte. Tallinn: Valgus.

Ariste, Paul 1977. Vadja muistendeid. Tallinn: Valgus.

Ariste, Paul 1982. Vadja pajatusi. Tallinn: Valgus.

Clancy, Steven J. 2010. The Chain of Being and Having in Slavic. (= Studies in Language Companion Series 122.) Philadelphia, Amsterdam: John Benjamins. http://dx.doi.org/10.1075/slcs.122

Dahl, Östen 2000a. Verbs of becoming as future copulas. - Tense and Aspect in the Languages of Europe. Ed. by Östen Dahl. Berlin, New York: Mouton de Gruyter, 351-361. http://dx.doi.org/10.1515/9783110197099.2.351

Dahl, Östen 2000b. The tense-aspect systems of European languages in a typological perspective. - Tense and Aspect in the Languages of Europe. Ed. by Östen Dahl. Berlin, New York: Mouton de Gruyter, 3-25. http:// dx.doi.org/10.1515/9783110197099.1.3

EM IX = Mari Mets, Anu Haak, Triin Iva, Grethe Juhkason, Mervi Kalmus, Miina Norvik, Karl Pajusalu, Pire Teras, Tuuli Tuisk, Lembit Vaba 2014. Lõunaeesti keelesaarte tekstid. (= Eesti murded IX.) Toim. Ellen Niit. Tallinn: Eesti Keele Instituut, Tartu Ülikool.

Erelt, Mati 2005. Source-marking resultatives in Estonian. - Linguistica Uralica 41 (1), 20-29.

Erelt, Mati 2017a. Öeldistäide - Eesti keele süntaks. Toim. Mati Erelt, Helle Metslang. (= Eesti keele varamu III.) Tartu: Tartu Ülikooli Kirjastus, 278-288.

Erelt, Mati 2017b. Öeldistäitemäärus - Eesti keele süntaks. Toim. Mati Erelt, Helle Metslang. (= Eesti keele varamu III.) Tartu: Tartu Ülikooli Kirjastus, 289-299.

Heine, Bernd 1993. Auxiliaries: Cognitive Forces and Grammaticalization. New York, Oxford: Oxford University Press.

Heine, Bernd, Tania Kuteva 2002. World Lexicon of Grammaticalization. Cambridge: Cambridge University Press. http://dx.doi.org/10.1017/ CBO9780511613463

Huumo, Tuomas 2007. Force dynamics, fictive dynamicity and the Finnish verbs of 'remaining'. - Folia Linguistica 41, 73-98. http://dx.doi.org/10.1515/ flin.41.1-2.73

Huumo, Tuomas, Jari Sivonen 2010. Conceptualizing change as deictic abstract motion: Metaphorical and grammatical uses of 'come' and 'go' in Finnish. - Meaning, Form, and Body. Ed. by Mark Turner, Fey Parrill, Vera Tobin. Stanford: CSLI Publications, 111-128. 
Ivulāne, Baiba 2015. Palīgnozīmē lietotu darbības vārdu sistēma latviešu valodā. Promocijas darbs. Latvijas Universitāte, humanitāro zinātṇu fakultāte. https://dspace.lu.lv/dspace/handle/7/28210 (04.02.2020).

Jokela, Hanna, Kirsi-Maria Nummila 2015. Become-constructions in Finnish and Estonian: Diachronic and contrastive perspectives. - Linguistica Uralica 51 (2), 81-99. http://dx.doi.org/10.3176/lu.2015.2.01

Kehayov jt 2013 = Petar Kehayov, Eva Saar, Miina Norvik, Andres Karjus 2013. Hääbuva kesklüüdi murde jälgedel suvel 2012. - Emakeele Seltsi aastaraamat 58 (2012). Peatoim. Mati Erelt. Tallinn: Teaduste Akadeemia Kirjastus, 58-101. http://dx.doi.org/10.3176/ESA58.04

Kettunen, Lauri 1920. Näytteitä etelävepsästä. Helsinki: Suomalaisen Kirjallisuuden Seura.

Kluge, Friedrich 1995. Etymologisches Wörterbuch der deutschen Sprache. 23. Aufl. Ed. by Elmar Seebold. Berlin: De Gruyter.

Kujola, Juho 1944. Lyydiläismurteiden sanakirja. (= Lexica Societatis FennoUgricae 9.) Helsinki: Suomalais-Ugrilainen Seura.

Laanest, Arvo 1966. Isuri murdetekste. Tallinn: Valgus.

Laanest, Arvo 1997. Isuri keele Hevaha murde sõnastik. Tallinn: Eesti Keele Instituut.

LK= Heikki Ojansuu, Juho Kujola, Jalo Kalima, Lauri Kettunen 1934. Lyydiläisiä kielennäytteitä. Helsinki: Suomalais-Ugrilainen Seura.

LVG = Latviešu valodas gramatika 2013. Ed. by Juris Grigorjevs, Daina Nīinna. Rīga: LU Latviešu valodas institūts.

Metslang, Helle 1994. Temporal relations in the predicate and the grammatical system of Estonian and Finnish. (= Oulun yliopiston ja saamen kielen laitoksen tutkimusraportteja 39.) Oulu: Oulun Yliopisto.

Metslang, Helle 1996. The development of the futures in the Finno-Ugric languages. - Estonian: Typological Studies I. (= Publications of the Department of Estonian of the University of Tartu 4.) Ed. by Mati Erelt. Tartu, 123-144.

Mägiste, Julius 1964. Liiviläisiä tekstejä. (= Suomalaisen Kirjallisuuden Seuran toimituksia 276.) Helsinki: Suomalaisen Kirjallisuuden Seura.

Nirvi, Ruben E. 1971. Inkeroismurteiden sanakirja. (= Lexica Societatis FennoUgricae XVIII.) Helsinki: Suomalais-Ugrilainen Seura.

Norvik, Miina 2012. Kesklüüdi lindistused. Isiklik kogu.

Norvik, Miina 2014a. Change-of-state predicates and their use in expressing the future: The case of Livonian. - Eesti ja soome-ugri keeleteaduse ajakiri / Journal of Estonian and Finno-Ugric Linguistics 5 (1), 117-148. http:// dx.doi.org/10.12697/jeful.2014.5.1.07

Norvik, Miina 2014b. Kesk- ja lõunavepsa lindistused. Isiklik kogu. 
Norvik, Miina 2015. Future Time Reference Devices in Livonian in a Finnic Context (= Dissertationes linguisticae Universitatis Tartuensis 25.) Tartu: Tartu Ülikooli Kirjastus.

Norvik, Miina 2020. The expression of CHANGE-OF-STATE in the Finnic languages. Open Linguistics.

Norvik, Miina, Külli Prillop 2017. The Estonian jääda and Livonian iedõ: Expressions of REMAIN and CHANGE in various grammatical constructions. - Eesti ja soome-ugri keeleteaduse ajakiri / Journal of Estonian and Finno-Ugric Linguistics 8 (2), 233-266. http://dx.doi.org/10.12697/ jeful.2017.8.2.08

NVM = Lauri Kettunen, Paavo Siro 1935. Näytteitä vepsän murteista. (= Mémoires de la Société Finno-Ougrienne LXX.) Helsinki: SuomalaisUgrilainen Seura.

Onikki-Rantajääskö, Tiina 2001. Sarjoja. Nykysuomen paikallissijaiset olotilanilmaukset kielen analogisuuden ilmentäjinä. Helsinki: Suomalaisen Kirjallisuuden Seura.

OVR = Мария Зайцева, Мария Муллонен 1969. Образцы вепсской речи. Академия Наук СССР, Карельский филиал. Ленинград: Наука.

Pajusalu, Renate 1994. Muutumisverbid eesti keeles ja nende vasted soome keeles. - Lähivertailuja 8, 83-97.

Pajusalu, Renate, Ilona Tragel 2007. Word and construction as units of categorization. The case of change predicates in Estonian. - Mental states, vol. 2: Language and Cognitive Structure. Ed. by Andrea C. Schalley, Drew Khlentzos. Amsterdam: John Benjamins, 289-310. http://dx.doi. org/10.1075/slcs.93.15paj

Pajusalu, Renate, Heili Orav 2008. Supiinid koha väljendajana: liikumissündmuse keelendamise asümmeetriast. - Emakeele Seltsi aastaraamat 53 (2007). Peatoim. Mati Erelt. Tallinn: Teaduste Akadeemia Kirjastus, 104-121.

Palmeos, Paula 1962. Karjala Valdai murrak. (= Emakeele Seltsi toimetised 5.) Tallinn: Eesti NSV Teaduste Akadeemia.

Porkka, Volmari 1885. Ueber den ingrischen Dialekt mit Berücksichtigung der übrigen finnisch-ingermanländischen Dialekte. Helsingfors: J. C. Frenckell \& Sohn.

Pustet, Regina 2003. Copulas. Universals in the categorization of the lexicon. (= Oxford Studies in Typology and Linguistic Theory.) Oxford: Oxford University Press.

Radden, Günter, René Dirven 2007. Cognitive English Grammar. Amsterdam, Philadelphia: John Benjamins. http://dx.doi.org/10.1075/clip.2

Setälä, Eemil N. 1953. Näytteitä liivin kielestä. (= Mémoires de la Société FinnoOugrienne 106.) Helsinki: Suomalais-Ugrilainen Seura. 
Zaiceva, Mullonen 2007 = Нина Зайцева, Мария Муллонен 2007. Новый русско-вепсский словарь. Петрозаводск: Периодика.

Timberlake, Alan 2004. A Reference Grammar of Russian. Cambridge: Cambridge University Press.

Tommola, Hannu 2010. Suunta ja muutos. Havaintoja viron ja suomen liikeverbeistä. - Eesti ja soome-ugri keeleteaduse ajakiri / Journal of Estonian and Finno-Ugric Linguistics 1 (2), 311-340. https://doi.org/10.12697/ jeful.2010.1.2.18

Tragel, Ilona, Külli Habicht 2012. Grammaticalization of the Estonian saama 'get'. - Linguistics 50 (6), 1371-1412.

Viitso, Tiit-Rein 2008. Liivi keel ja läänemeresoome keelemaastikud. Tartu, Tallinn: Eesti Keele Sihtasutus.

VISK = Iso suomen kielioppi verkkoversio. http://scripta.kotus.fi/visk/etusivu. php (30.09.2018).

VKS = Elna Adler, Silja Grünberg, Merle Leppik 2013. Vadja keele sõnaraamat. Tallinn: Eesti Keele Sihtasutus. 


\section{Lisa}

Tabel 10. Verbide esinemus keelte kaupa

\begin{tabular}{|l|r|r|r|r|r|r|r|}
\hline Verb/Keel & isuri & lutsi & lüüdi & V. karj & vadja & vepsa & Kokku \\
\hline JÄÄDA & 14 & 18 & 1 & 4 & 18 & 9 & $\mathbf{6 4}$ \\
\hline SAADA & 11 & 78 & & & 2 & & $\mathbf{9 1}$ \\
\hline LEEDA & 18 & & 48 & 90 & 32 & 24 & $\mathbf{2 1 2}$ \\
\hline SÜNDIDA & 1 & & 47 & 6 & & & $\mathbf{5 4}$ \\
\hline TULLA & 46 & 1 & 3 & & 41 & 9 & $\mathbf{1 0 0}$ \\
\hline MINNA & 10 & 2 & 1 & & 7 & 2 & $\mathbf{2 2}$ \\
\hline TEHA & & 1 & & & & 56 & $\mathbf{5 7}$ \\
\hline Kokku & $\mathbf{1 0 0}$ & $\mathbf{1 0 0}$ & $\mathbf{1 0 0}$ & $\mathbf{1 0 0}$ & $\mathbf{1 0 0}$ & $\mathbf{1 0 0}$ & $\mathbf{6 0 0}$ \\
\hline
\end{tabular}

Tabel 11. Lausetüüpide esinemus keelte kaupa

\begin{tabular}{|l|r|r|r|r|r|r|r|}
\hline Verb/Keel & isuri & lutsi & lüüdi & V. karj & vadja & vepsa & Kokku \\
\hline Nl_Tra & 36 & 17 & 4 & 1 & 23 & 8 & $\mathbf{8 9}$ \\
\hline Nl_Ess & & & & 1 & 2 & 1 & $\mathbf{4}$ \\
\hline Nl_Nom & 13 & 33 & 21 & 38 & 16 & 23 & $\mathbf{1 4 4}$ \\
\hline Nl_Adv & 15 & 5 & 3 & 11 & 10 & 5 & $\mathbf{4 9}$ \\
\hline Tu & 3 & 6 & 5 & 1 & 3 & 5 & $\mathbf{2 3}$ \\
\hline Ko & 5 & 7 & 14 & 14 & 5 & 10 & $\mathbf{5 5}$ \\
\hline Ol & 22 & 27 & 40 & 26 & 33 & 33 & $\mathbf{1 8 1}$ \\
\hline Om & 6 & 5 & 13 & 8 & 8 & 15 & $\mathbf{5 5}$ \\
\hline Kokku & $\mathbf{1 0 0}$ & $\mathbf{1 0 0}$ & $\mathbf{1 0 0}$ & $\mathbf{1 0 0}$ & $\mathbf{1 0 0}$ & $\mathbf{1 0 0}$ & $\mathbf{6 0 0}$ \\
\hline
\end{tabular}

Tabel 12. Lausetüüpide esinemus verbide kaupa

\begin{tabular}{|l|c|r|r|r|r|r|r|r|}
\hline $\begin{array}{c}\text { Verb/ } \\
\text { Keel }\end{array}$ & JÄÄDA & SAADA & LEEDA & $\begin{array}{c}\text { SÜN- } \\
\text { DIDA }\end{array}$ & TULLA & MINNA & TEHA & Kokku \\
\hline Nl_Tra & 30 & 15 & 2 & 2 & 24 & 12 & 4 & $\mathbf{8 9}$ \\
\hline Nl_Ess & & & 4 & & & & & $\mathbf{4}$ \\
\hline Nl_Nom & 2 & 32 & 62 & 11 & 17 & & 20 & $\mathbf{1 4 4}$ \\
\hline Nl_Adv & 11 & 4 & 19 & 1 & 4 & 9 & 1 & $\mathbf{4 9}$ \\
\hline Tu & & 6 & 7 & & 7 & 1 & 2 & $\mathbf{2 3}$ \\
\hline Ko & & 7 & 21 & 8 & 10 & & 9 & $\mathbf{5 5}$ \\
\hline Ol & 10 & 22 & 75 & 23 & 37 & & 14 & $\mathbf{1 8 1}$ \\
\hline Om & 11 & 5 & 22 & 9 & 1 & & 7 & $\mathbf{5 5}$ \\
\hline Kokku & 64 & 91 & 212 & 54 & 100 & 22 & 57 & $\mathbf{6 0 0}$ \\
\hline
\end{tabular}




\title{
General change-of-state predicates and associated clause types in the Finnic languages
}

\author{
MIINA NORVIK
}

Change-of-state can be associated with inchoative meanings, transition from one state to another, usually with the focus on the new state, but it can also be linked to the emergence of a situation or an entity, or change of possession. In every Finnic language, there tends to be one such predicate that is used to express change, but it is never the only one. This paper presents an analysis of the usage of seven predicates - BE BORN, BECOME, COME, DO, GO, REMAIN, WILL $\mathrm{BE}$ - that can be employed to convey change in the Finnic languages.

The article set out to compare similarities/differences in the use of the aforementioned predicates in five intransitive clause types: (i) unmarked clauses, (ii) elative-marked result clauses, (iii) experiential clauses, (iv) existential clauses, and (v) possessive clauses. The aim was to see what meaning nuances can be associated with these clause types, how the clause types are interrelated and what this reveals about the frequency of use of various predicates in a language. The main attention was devoted to six Finnic varieties: Ingrian, Ludian, Lutsi (a language island of Estonian), Valdai Karelian, Veps, and Votic. The data used in the study originated from various collections of text, language corpora, dictionaries, and my own fieldwork data. In the final data set, each language was represented with 100 examples. Finnish, Estonian, and Livonian were included in the study based on previous results.

The study showed that the greatest variety of predicates (typically 3 out of 7) was used in existential clauses, which express emergence of a situation or an entity. Existential clauses were all in all the commonest in the data set (212 occurrences among 600 examples). Furthermore, some predicates in a language could only be found in this type (e.g. all the uses of TULLA in Veps belonged to this type). As a result, it was regarded as the most central clause type, which is most probably responsible for the spread of change-of-state predicates. Existential clauses showed connections with all other clause types, both directly as well as indirectly. Whereas unmarked clauses and elative-marked result clauses most commonly expressed change from state $1 \rightarrow$ state 2 , they could also be found to express an emergence of something in a similar way to existential clauses. In possessive and experiential clauses, the connection was especially evident if 
one would leave out the possessee or the change experiencer, respectively. As a result, they could be easily subsumed under existential clauses in such a case. To compare, while in existential clauses about three different predicates occurred, experiential clauses could typically be associated with the predicate that is most generally used in the respective language.

In general, the paper showed that the choice of change-of-state predicates depends on several factors. In addition to the differences in the occurrence of verbs in various clause types, the choice between various predicates also revealed lexical differences. For instance, especially GO and REMAIN appeared in fixed expressions or could be associated with specific meanings. Time reference turned out to play a role as well. For instance, in Veps, the expression of change in relation to the past was most typically expressed by means of DO (54/56 examples of DO occurred in the past tense), while in connection with the future WILL BE was used. In Valdai Karelian, in turn, the same predicate was used regardless of time reference. In the case of Valdai Karelian and Veps WILL BE, but also Ludian BE BORN and Lutsi BECOME, it was also possible to find usages where in connection with the future the expression of change was backgrounded and the following state foregrounded, which thus suggests the development CHANGEOF-STATE $\rightarrow$ FUTURE.

Keywords: morphosyntax, intransitive constructions, semi-copula, Finnic languages

\author{
Miina Norvik \\ eesti ja üldkeeleteaduse instituut \\ Tartu Ülikool \\ Jakobi 2 \\ 51014 Tartu \\ miina.norvik@ut.ee
}

